\title{
The Late Quaternary History of Atmospheric Trace Gases and Aerosols: Interactions Between Climate and Biogeochemical Cycles
}

\author{
D. Raynaud \\ Laboratoire de Glaciologie et de Géophysique de l'Environnement, LGGE Centre National de la Recherche \\ Scientifique, 54 Rue Molière, FR-38402 Saint-Martin-d'Hères, France \\ T. Blunier \\ Climate \& Environmental Physics, Physics Institute, University of Bern, Sidlerstrasse 5, 3012 Bern, \\ Switzerland \\ Y. Ono \\ Laboratory of Geoecology, Graduate School for Environmental Earth Science, Hokkaido University \\ Kita10 Nishi5, Kita-ku, Sapporo, Hokkaido 60, Japan \\ R. J. Delmas \\ Laboratoire de Glaciologie et Géophysique de l'Environnement, Domaine Universitaire B.P. 96, Saint Martin \\ d'Hères Cedex, 38402 France \\ Contributors: J-M. Barnola, F. Joos, J-R. Petit, R. Spahni
}

\subsection{Introduction: anthropogenic and natural changes}

Human activities perturb the atmosphere and thereby influence the global climate. Prominent examples are greenhouse trace gases and sulfate aerosols which both affect the radiative balance at the surface of the Earth. This is also true for black carbon and organic carbon aerosols emitted by burning of biomass and fossil fuel, as well as eolian mineral dust originating from changes in land use and land cover.

Given these ongoing anthropogenic changes, understanding the past record of atmospheric composition is important for several reasons:

- Over the past hundred years it is not always an easy task to separate atmospheric changes induced by human activities from those related to natural variability. Only the longer term past record provides the context of natural variability within which recent anthropogenic perturbation has taken place.

- The rate of anthropogenic perturbation is very high. Since 1750 the atmospheric $\mathrm{CO}_{2}$ concentration has increased by $30 \%$ and $\mathrm{CH}_{4}$ by $150 \%$. Did similar rates occur in the past and, if so, how did they affect climate and environment?

- Complex feedback mechanisms exist between the climate system and the trace gas content of the atmosphere. Past changes can be used to study such atmosphere-climate feedbacks and the processes involved.

- The paleorecord offers a unique opportunity to test the ability of climate models to simulate interactions between atmospheric composition and climate, under different climatic conditions.

The Earth has experienced major changes in its atmospheric composition over the past several hundred thousand years. During this time, atmospheric composition and climate have interacted alongside external influences (or forcings), such as changes in the pattern of solar radiation incident on the Earth's surface. The aim of this chapter is to review the history of atmospheric composition as it interacted with climate during the last four major climatic cycles (roughly the last 400,000 years). We concentrate on processes operating on time scales covering the interval between 100,000 years and a century. There are two major reasons for choosing this time period: (1) the atmospheric record further back in time is generally not well documented and (2) the last four glacial cycles encompass a wide spectrum of climatic conditions.

In this chapter, we begin with a brief introduction on past variations of greenhouse gases and aerosols during several different, climatically significant periods of the past: glacial-interglacial cycles (section 2.3), abrupt climatic changes (section 2.4), the Holocene (section 2.5), and the last millennium (section 2.6). In the last section (2.7) we highlight 
significant conclusions that can be drawn in terms of climate and biogeochemical cycles. The following section (2.1) is devoted to explaining the significance of the ice core archive of atmospheric gases and aerosols.

\subsubsection{Greenhouse gases}

Greenhouse gases are transparent to incoming solar radiation but opaque to the infrared radiation emitted by the earth's surface. The main greenhouse gas is water vapor whose atmospheric content is dominantly influenced by climatic conditions, primarily temperature. Water vapor concentration in the atmosphere varies widely in space and time, though its long term temporal variability is not well constrained by data. It is worth noting that the direct emission of water vapor by human activities is negligible compared to natural fluxes. Other greenhouse gases exist in much smaller concentrations in the atmosphere, but their increase due to anthropogenic activities may drastically affect our future climate. Most of them, such as $\mathrm{CO}_{2}, \mathrm{CH}_{4}, \mathrm{~N}_{2} \mathrm{O}$ and tropospheric ozone were present in the atmosphere prior to the changes brought about by anthropogenic activities. Some trace-gases, like CFC's, exist solely due to humans.

Some trace gases, which are not themselves radiatively active, nonetheless interact through atmospheric chemistry processes with greenhouse gases. $\mathrm{CO}$, for example, although not itself a greenhouse gas is involved in setting the oxidizing capacity $(\mathrm{OH}$ cycle) of the atmosphere, and therefore affects the atmospheric sink of $\mathrm{CH}_{4}$.

\subsubsection{Aerosols}

An aerosol is a suspended liquid or solid particle in a gas. Aerosols constitute a minor $(\sim$ one $\mathrm{ppb}$ by mass) but important component of the atmosphere. Indeed, aerosols play an active role in atmospheric chemistry. Natural aerosols may be divided into two classes, primary and secondary aerosols, arising from two different basic processes:

Primary aerosols derive from the dispersal of fine materials from the earth's surface. There are two major categories of natural primary aerosols: sea salt and soil dust. Most sea salt particles are produced by evaporation of spray from breaking waves at the ocean surface whereas mineral dust particles are mostly generated by winds in arid continental regions and, sporadically, by explosive volcanic eruptions which emit huge amounts of ash particles. The continental sediments formed during glacial periods by the deposition of wind blown dust are called loess.
Secondary aerosols are formed by chemical reactions and condensation of atmospheric gases and vapors. The sulfur cycle dominates the tropospheric secondary aerosol budget. In pre-industrial conditions, it is mainly linked to marine biogenic activity, which produces large amounts of gaseous dimethylsulfide (DMS). Once in the atmosphere, DMS oxidizes primarily into sulfuric acid, ultimately present in the atmosphere in the form of fine aerosol droplets. This fine aerosol is also partly of volcanic origin. Presently, anthropogenic $\mathrm{SO}_{2}$ emission linked to fossil fuel, biomass burning and industrial processes dominates over all natural sources of atmospheric sulfur. In addition, it has been suggested recently that organic matter, frequently associated with sulfur species, may constitute a major fraction of secondary aerosol particles. Organic carbon and "black carbon" (called soot) are the main organic aerosol particles. They are primarily produced by the emission of smoke from biomass burning.

Primary and secondary particles may interact strongly in the atmosphere, turning atmospheric aerosols into a very complex mixture. They are removed from the air by both dry and wet deposition.

Atmospheric aerosols influence climate in two ways: directly through reflection and absorption of solar radiation, and indirectly by modifying the optical properties and lifetimes of clouds. In addition to ash, large explosive volcanic eruptions sporadically inject (a few times per century) huge amounts of $\mathrm{SO}_{2}$ into the stratosphere. The sulfuric acid veil formed after such eruptions may persist for several years at an elevation of about $20 \mathrm{~km}$, markedly cooling the global climate.

Dust, be it desert, volcanic or soot particles, when deposited on the surface of snow and ice may decrease its albedo and enhance surface melting. This process, along with high altitude temperature increases, is contributing to the retreat of glaciers and snowfields in high mountain areas worldwide. It has even been suggested that bacteria living on the surface of glaciers could be nourished by these aerosol deposits, further changing the albedo and melting rate.

Large amounts of mineral substances (e.g. iron, nitrate, phosphorous) are transported as aerosols. In some cases, these substances can act as nutrients, enhancing marine biogenic activity and the rate of the atmospheric $\mathrm{CO}_{2}$ sequestration in the ocean. Moreover, continental carbonate aerosol inputs may potentially change the alkalinity of shallow oceanic layers, modifying surface ocean chemistry and consequently air/sea exchanges of $\mathrm{CO}_{2}$. Since atmospheric dust concentrations were strongly en- 
hanced during glacial periods, these processes must be considered in paleoclimatic studies.

As previously mentioned, dimethylsulfide (DMS) is produced in the ocean by marine biogenic activity. This gas is the primary natural source of atmospheric sulfate. Non-sea-salt sulfate (or nss- $\mathrm{SO}_{4}$ ) and methanesulfonic acid (MSA) are the two most important compounds formed as DMS is oxidized in the atmosphere. MSA is of particular interest in that it is uniquely attributable to marine biogenic activity. When oxidized in the atmosphere, DMS forms acidic gases or fine aerosols which are a major source of cloud condensation nuclei. It has been proposed that a higher emission rate of DMS may lead to an albedo increase due to enhanced cloud cover which, consequently, decreases absorption of solar radiation and lowers surface temperature (Liss et al. 1997, Charlson et al. 1998). This climatic process can in turn influence the rate of DMS production. If a sea-surface temperature (SST) decrease were to enhance production of DMS, it would provide a positive feedback to SSTs. However, both the direction and magnitude of this feedback is currently unknown (Watson and Liss 1998).

The determination of MSA in polar ice is relatively recent (Saigne and Legrand 1987) and there are indications that MSA ice records may suffer post-deposition modifications (Mulvaney et al. 1992). Measurements at Vostok Station suggest that 80 to $90 \%$ of this compound may have escaped the ice matrix in the first few meters (Wagnon et al. 1999). This finding casts doubts on the actual significance of MSA concentrations measured in polar ice cores. Despite these difficulties, MSA has become a species of primary importance in ice core studies: it has been proposed as a tool for reconstructing the past history of major El Niño events (Legrand and Feniet-Saigne 1991) and documenting the co-variations of marine biogenic activity with known past climate variability (Legrand et al. 1991, Legrand et al. 1992). Furthermore, it has been proposed that marine biogenic activity might be regulated by atmospheric deposition of continental dust, containing $\mathrm{Fe}$ and nitrate onto the ocean surface, particularly in high nutrient low productivity areas (chapter 4). However, it has yet to be demonstrated that marine biogenic activity was actually enhanced during ice ages due to higher dust input to the ocean.

Anthropogenic activities increase the amount of secondary particles in the atmosphere, as well as soot. The majority of anthropogenic aerosols exist in the form of sulfate and carbon, but also of nitrogen compounds (e.g. nitrate and ammonium). Presently, anthropogenic activities contribute approximately $20 \%$ to the global aerosol mass burden, but up to $50 \%$ to the global mean aerosol optical depth. It is generally accepted that the net global radiative forcing due to anthropogenic aerosols is significant and negative (i.e. it tends to cool the average global temperature) (Sato et al. 1993). However, quantification of their climatic effects remains difficult, in particular due to large uncertainties associated with the indirect impact of aerosols on clouds.

\subsection{The significance of past atmospheric records}

\subsubsection{Aerosol incorporation and gas occlusion in ice}

Gaseous and particulate impurities are mostly advected from low and mid latitudes to the polar areas by wind, generally in the troposphere, though sometimes by a stratospheric pathway. Local sources are generally negligible.

Aerosol particles are incorporated in snowflakes by nucleation scavenging at cloud level, by belowcloud scavenging (this process is, however, rather unimportant in clean air conditions) and by dry deposition onto the snow surface. It is generally accepted that wet deposition is dominant when the accumulation rate is high $\left(>20 \mathrm{~g} \mathrm{~cm}^{-2} \mathrm{yr}^{-1}\right)$. On the other hand, at low accumulation sites, such as Dome $\mathrm{C}$ and Vostok stations in central Antarctica, dry deposition dominates. At Vostok, where accumulation is currently $2.3 \mathrm{~g} \mathrm{~cm}^{-2} \mathrm{yr}^{1}$, dry deposition contributes probably up to $80 \%$, except for acid species such as $\mathrm{HNO}_{3}, \mathrm{HCl}, \mathrm{MSA}$ and carboxylic acids, for which the dry deposition process seems to be negligible. Moreover, the stability of these species in firn is questionable, in particular at very low accumulation sites (De Angelis, 1995; Wagnon et al. 1999, Wolff 1996).

The relationships linking snow chemistry to atmospheric concentrations (the so-called "transfer functions") are still not fully elucidated for aerosol species and reactive gases. In many cases, glaciochemists have used empirical formulas to interpret the ice records in terms of past atmospheric composition, assuming that the processes involved in the transfer function did not change under different climate conditions and are therefore well represented by the empirical relation. Lack of understanding of the transfer processes is a critical point in our interpretation of the past aerosol records.

Regarding air composition, glaciers and ice sheets are unique as they are the only paleoarchives which directly record atmospheric composition in the form of trapped air bubbles. The top layer (roughly the first 50 to $130 \mathrm{~m}$ ) is formed by porous firn, which is not yet consolidated ice. Atmospheric air exchanges 
with the air in this layer. Air in the porous firn thus consists of a mixture of air that was last in equilibrium with the atmosphere at different times (Schwander 1996). As a consequence, at a given time, the concentrations of gas species in the firn are not the same as their atmospheric concentrations due to physical, and (in case of reactive gases) chemical, processes. Air occluded in ice at the bottom of the firn column does not have an exact age reflecting its last contact with the atmosphere, but an age distribution. Thus the temporal resolution of any trace gas record from ice cores is inherently limited. This age distribution is a function of both temperature and accumulation, which are highly variable from site to site (Table 2.1). Generally, it increases with decreasing temperature and accumulation. The width of the age distribution is as low as 7 years at high accumulation/ high temperature sites but can be several centuries for Antarctic low accumulation/ low temperature sites (Schwander and Stauffer 1984).

In the top few meters of firn, air is well mixed by convection and so has essentially the same composition as the atmosphere. Below this zone the air in the firn is static and mixes mainly by molecular diffusion. An equilibrium between molecular diffusion and gravitational settling is reached for each gas component (Craig et al. 1988, Schwander and Stauffer 1989). As a consequence, two gas components with different molecular weights fractionate with depth relative to their initial relationship in the atmosphere. The magnitude of this fractionation is well known, allowing an accurate, corrected ice core record to be constructed. The process is most important for isotope records but can be neglected when dealing with concentration records.

Another consequence of the air occlusion at the bottom of the firn column is that the age of the air in an occluded air bubble is less than the age of the surrounding ice. This age difference ( $\Delta$ age hereafter) is the difference between the age of the ice and the mean age of the air at the depth of occlusion. The age of the ice at close off is the dominant term of $\Delta$ age. $\Delta$ age can be calculated using a model for the firn densification process. Although the process is well understood, the accuracy of the calculation is limited due to uncertainty in past accumulation and temperature. However, $\Delta$ age calculated with the densification model is in excellent agreement with independent measurements of $\Delta$ age based on temperature diffusion processes in the firn for central Greenland ice cores (Severinghaus et al. 1998, Leuenberger et al. 1999, Severinghaus and Brook 1999). $\Delta$ age can be substantial. Under present day conditions $\Delta$ age is on the order of a few centuries for high accumulation/ high temperature sites like
Central Greenland (Schwander et al. 1993). At Vostok, where accumulation and temperature are low, $\Delta$ age is about 3000 years (Schwander and Stauffer 1984, Barnola et al. 1991). Under colder climate conditions, which is paralleled by lower accumulation, $\Delta$ age increases significantly.

Below the close off zone the air bubbles shrink in size as the ice flows to deeper strata under the increasing pressure of overlying layers. When the pressure gets high enough the gas is transformed from air bubbles into air hydrates (Miller 1969). For example, first hydrate formation has been observed at $500 \mathrm{~m}$ depth at Vostok and $1022 \mathrm{~m}$ at Summit Greenland, respectively (Shoji et al. 2000). Hydrates decompose into bubbles again once the core is recovered and relaxed. However, a full reformation of air bubbles takes several decades.

\subsubsection{How reliable are the climate records obtained from ice cores?}

How sure are we that the measured gas composition represents the atmospheric concentrations at trapping time? As pointed out above, the record of atmospheric gas composition is smoothed in the ice. This smoothing may be significant and averages over centuries for Vostok station (Schwander and Stauffer 1984, Barnola et al. 1991, Rommelaere et al. 1997), where the accumulation rate is very low and the temperature among the coldest. Would a concentration increase like the one we observe over the last few centuries be visible in the Vostok record? In Figure 2.1 we show how the present anthropogenic $\mathrm{CO}_{2}$ increase would be recorded at Vostok. For simulating the changes in atmospheric $\mathrm{CO}_{2}$ concentrations after the year 2000 we use the Bern model (Joos et al. 1996). As a lower limit for the future $\mathrm{CO}_{2}$ concentration we set the anthropogenic $\mathrm{CO}_{2}$ emission to zero after the year 2000. The smoothed "Vostok record" is obtained using the Schwander model for gas occlusion (Schwander et al. 1993) with an extension for gradual gas occlusion over the close off interval (Spahni, in preparation). The resulting concentration propagation with a maximum of about 315 ppmv and a very slow decrease to the pre-industrial background clearly stands out. At no place in the Vostok record has such a high concentration with such a concentration trend been measured. Strictly speaking the Vostok record does not exclude a pulse-like atmospheric $\mathrm{CO}_{2}$ signal of a few decades duration with concentrations as high as today. However, this would require both a large carbon release (order $200 \mathrm{GtC}$ ) and an equally large uptake within a few decades only. Such an oscillation is not compatible with our present view of the global carbon cycle. 
Table 2.1. Characteristics of selected ice cores

\begin{tabular}{|c|c|c|c|c|c|}
\hline PLACE & NAME & LOCATION & $\begin{array}{l}\text { ELEVATION } \\
\text { (m.a.s.1.) }\end{array}$ & $\begin{array}{c}\text { ACCUMULATION } \\
\left(\mathrm{cm} \text { ice } \mathrm{a}^{-1}\right)\end{array}$ & $\begin{array}{l}\text { TEMP. } \\
\left({ }^{\circ} \mathrm{C}\right)\end{array}$ \\
\hline Greenland & GISP & $72^{\circ} 36^{\prime} \mathrm{N}, 38^{\circ} 30^{\prime} \mathrm{W}$ & 3214 & 25 & -31.4 \\
\hline Greenland & GRIP & $72^{\circ} 35^{\prime} \mathrm{N}, 37^{\circ} 38^{\prime} \mathrm{W}$ & 3238 & 23 & -31.7 \\
\hline Peru & Huascáran & $9^{\circ} 07^{\prime} \mathrm{S}, 77^{\circ} 37^{\prime} \mathrm{W}$ & 6048 & 140 & -9.8 \\
\hline Antarctica & $\begin{array}{l}\text { Law Dome } \\
\text { (DSS) }\end{array}$ & $66^{\circ} 46^{\prime} \mathrm{S}, 112^{\circ} 48^{\prime} \mathrm{E}$ & 1370 & 60 & -22 \\
\hline Antarctica & D47 & $67^{\circ} 23^{\prime} \mathrm{S}, 137^{\circ} 33^{\prime} \mathrm{E}$ & 1550 & 30 & -25 \\
\hline Antarctica & H15 & $69^{\circ} 05^{\prime} \mathrm{S}, 40^{\circ} 47^{\prime} \mathrm{E}$ & 1057 & 26 & -20.5 \\
\hline Antarctica & Dome C & $75^{\circ} 06^{\prime} \mathrm{S}, 123^{\circ} 24^{\prime} \mathrm{E}$ & 3233 & 2.7 & -54 \\
\hline Antarctica & Vostok & $78^{\circ} 28^{\prime} \mathrm{S}, 106^{\circ} 48^{\prime} \mathrm{E}$ & 3488 & 2 & -55 \\
\hline Antarctica & Byrd & $80^{\circ} 01^{\prime} \mathrm{S}, 119^{\circ} 31^{\prime} \mathrm{W}$ & 1530 & 11.2 & -28 \\
\hline Antarctica & South Pole & $90^{\circ} \mathrm{S}$ & 2835 & 8 & -49.4 \\
\hline
\end{tabular}

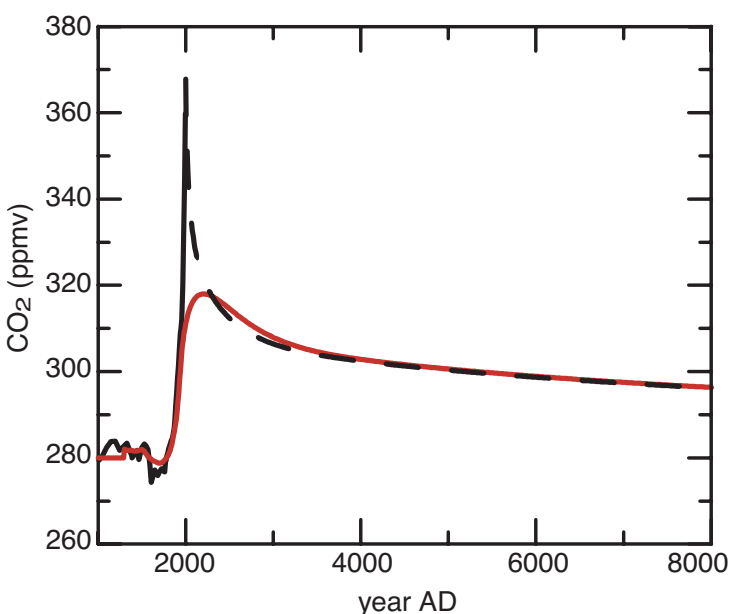

Fig. 2.1. Smoothing of the anthropogenic $\mathrm{CO}_{2}$ increase at Vostok. Solid line: Atmospheric $\mathrm{CO}_{2}$ concentration from ice cores and atmospheric measurements up to the year 2000. Dotted line: Propagation of the atmospheric $\mathrm{CO}_{2}$ concentration calculated with the Bern model (Joos et al. 1996) setting the hypothetical anthropogenic carbon source to zero after the year 2000. Red solid line: prediction of how the atmospheric signal would be recorded in the Vostok ice core, calculated with the Schwander model for gas occlusion (Schwander et al. 1993) with an extension for gradual gas occlusion over the close off interval (Spahni in preparation).

Not all glaciers and ice sheets are equally useful regarding the past atmospheric composition. Where melting occurs, gas content and gas composition may be altered by chemical reactions taking place in aquatic systems or by physical gas exchange between the gaseous and the aquatic sections. In Greenland and Antarctica surface melting is sporadic. At these sites the gas occlusion occurs by dry sintering of the firn described above. As soon as there is melting the trapping gets more complex and erratic. Melt layers may block the exchange to the overlying atmosphere and due to the solubility of gases the gas composition in the melt layer may change tremendously. Such "wet trapping" is mostly observed in Alpine and mid latitude glaciers. Under dry, cold conditions of polar areas no chemical reactions were observed during the trapping of trace gases. This is demonstrated by the generally good match of atmospheric and ice core data. However, very slow chemical reactions are able to alter gas concentrations in ice cores due to the long time available for the reaction to proceed. This has been observed in Greenland where high impurities in the ice leads to significant in situ $\mathrm{CO}_{2}$ production via acid-carbonate interactions and oxidation of organic material (Delmas 1993, Anklin et al. 1997, Haan and Raynaud 1998). It has been demonstrated that the Antarctic records provide the most reliable data of changes in global atmospheric $\mathrm{CO}_{2}$ (Raynaud et al. 1993), probably within a few ppmv. Antarctic results are consistent despite the fact that the coring sites have different accumulation, temperature and impurities. $\mathrm{CO}_{2}$ measurements made several years apart on the same core show no significant changes. Bacterial activity has the potential to alter the trace gas composition and its isotopic signature. Viable bacteria have been found in several ice cores to significant depths (Abyzov et al. 1993, Christner et al. 2000). Bacterial formation of trace gases is probably important in temperate glaciers, where much organic matter is trapped in the ice. In polar regions the bacterial concentration is lower and bacterially induced alteration of the trace gas composition has yet to be confirmed. However, $\mathrm{N}_{2} \mathrm{O}$ measurements from the Vostok ice core for the penultimate glacial period show values that are suspected to originate from in situ bacterial production (Sowers 2001). This hypothesis is supported by the fact that the layers with unusual $\mathrm{N}_{2} \mathrm{O}$ values 
contain high dust content, which may correlate with high bacterial content (Christner et al. 2000). In another ice core from Greenland, unreasonably high values have been found sporadically. However, in general, $\mathrm{N}_{2} \mathrm{O}$ results from old and new cores from the northern and the southern hemisphere agree (Flückiger et al. 1999). The significance of bacterial alteration for trace gas records (especially $\mathrm{N}_{2} \mathrm{O}$ ) has yet to be demonstrated.

A further consideration is post-coring effects from storage and contamination during the extraction of the ice. These effects are important when analyzing trace metals or the isotopic composition of gases, but are generally not important with respect to the concentration measurements discussed here.

\subsection{Glacial-interglacial cycles}

Figure 2.2 provides a longer-term perspective on atmospheric trace gas changes over 4 glacialinterglacial cycles covering roughly the last 400,000 years.

\subsubsection{Greenhouse gases}

The Vostok ice core shows a remarkable correlation between temperature and greenhouse gas concentrations on glacial-interglacial scales (Figure 2.2 Petit et al. 1999). Concentrations are generally higher during interglacials than during glacials. Although there is no continuous, quantitative proxy record for water vapor, the most important greenhouse gas, it was certainly lower during cold and dry glacial periods. $\mathrm{CO}_{2}$ concentrations oscillate between 180-200 ppmv during the coldest glacial periods and 280-300 ppmv during full interglacials. The $\mathrm{CH}_{4}$ concentration is about 700 ppbv during interstadials and only half of that during cold periods. Model results indicate that changes in the oxidizing capacity of the atmosphere can explain only $10-30 \%$ of this variability (Thompson 1992). Therefore the changes must have been caused by changes in the sources of this gas. A complete record of the $\mathrm{N}_{2} \mathrm{O}$ concentration over glacial-interglacial cycles does not exist. However, measurements over the last termination and during millennial scale Dansgaard-Oeschger events indicate variations with the same general pattern as for $\mathrm{CH}_{4}$, with lower concentrations during cold periods (Flückiger et al. 1999). The Vostok $\mathrm{N}_{2} \mathrm{O}$ record indicates values for the last interglacial similar to those recorded during the pre-industrial period in other cores (Sowers 2001); as already mentioned in section 2.2, the $\mathrm{N}_{2} \mathrm{O}$ record for the penultimate glacial period is potentially altered, possibly by bacterial activity (Sowers 2001).

The average rates of concentration changes between glacial-interglacial conditions are much smaller than those observed for the period covering the last 250 years (industrial era): about 35, 120 and 25 times slower for $\mathrm{CO}_{2}, \mathrm{CH}_{4}$ and $\mathrm{N}_{2} \mathrm{O}$, respectively.

One outstanding question on glacial-interglacial time scales is why atmospheric $\mathrm{CO}_{2}$ rose by 80 to 100 ppmv during glacial to interglacial warmings. There is no doubt that the ocean must have played a major role since it represents the largest pool of available $\mathrm{CO}_{2}$ that could have been delivered directly to the atmosphere, and because the rapidly expanding continental biosphere probably acted as a $\mathrm{CO}_{2}$ sink during these major warming periods. There is a third player, namely changing rates of weathering of silicate and carbonate rocks. Although it certainly played a role, this process is too slow to explain the rapidity of transitions seen in the Vostok record. We can therefore assert that the 170$190 \mathrm{Gt}$ of carbon, which accumulated in the atmosphere during the several millennia corresponding to glacial to interglacial transitions, must have been the result of a net flux out of the oceans. This is a minimum estimate, since during the same time the uptake of atmospheric $\mathrm{CO}_{2}$ by the continental biosphere, although not well constrained, was almost certainly positive. Estimates for this continental uptake range between 0 and $1200 \mathrm{GtC}$ with a best estimate of around $400 \mathrm{GtC}$. In conclusion, there must have been a transfer of several hundred to about one thousand gigatons of carbon from the ocean to the atmosphere and terrestrial ecosystems during glacial-interglacial transitions. The role of the different processes in explaining glacialinterglacial variability in $\mathrm{CO}_{2}$ is discussed in Chapter 4.

The sequence of events between $\mathrm{CO}_{2}$ and temperature in the glacial-interglacial record of ice cores indicates that the warming at high southern latitudes slightly preceded the start of the $\mathrm{CO}_{2}$ increase (Petit et al. 1999, Pépin et al. in press, Monnin et al. 2001). This highlights the fact that changes of $\mathrm{CO}_{2}$, as well as of other greenhouse trace-gases, at the scale of the glacial-interglacial cycles have been forced by climatic mechanisms acting on their different reservoirs. Then, the real question is: how large has the role of changing greenhouse trace-gases been, in forcing the observed climate changes?

The initial forcing due to the direct radiative effect of increasing greenhouse trace-gases $\left(\mathrm{CO}_{2}+\right.$ $\mathrm{CH}_{4}+\mathrm{N}_{2} \mathrm{O}$ ) during the glacial-interglacial transitions is estimated to have produced a global warming of about $0.95^{\circ} \mathrm{C}$ (Petit et al. 1999). This initial forcing would have been amplified by rapid feedbacks due to associated water vapor and albedo modifications (sea ice, clouds, etc.), as is also the 


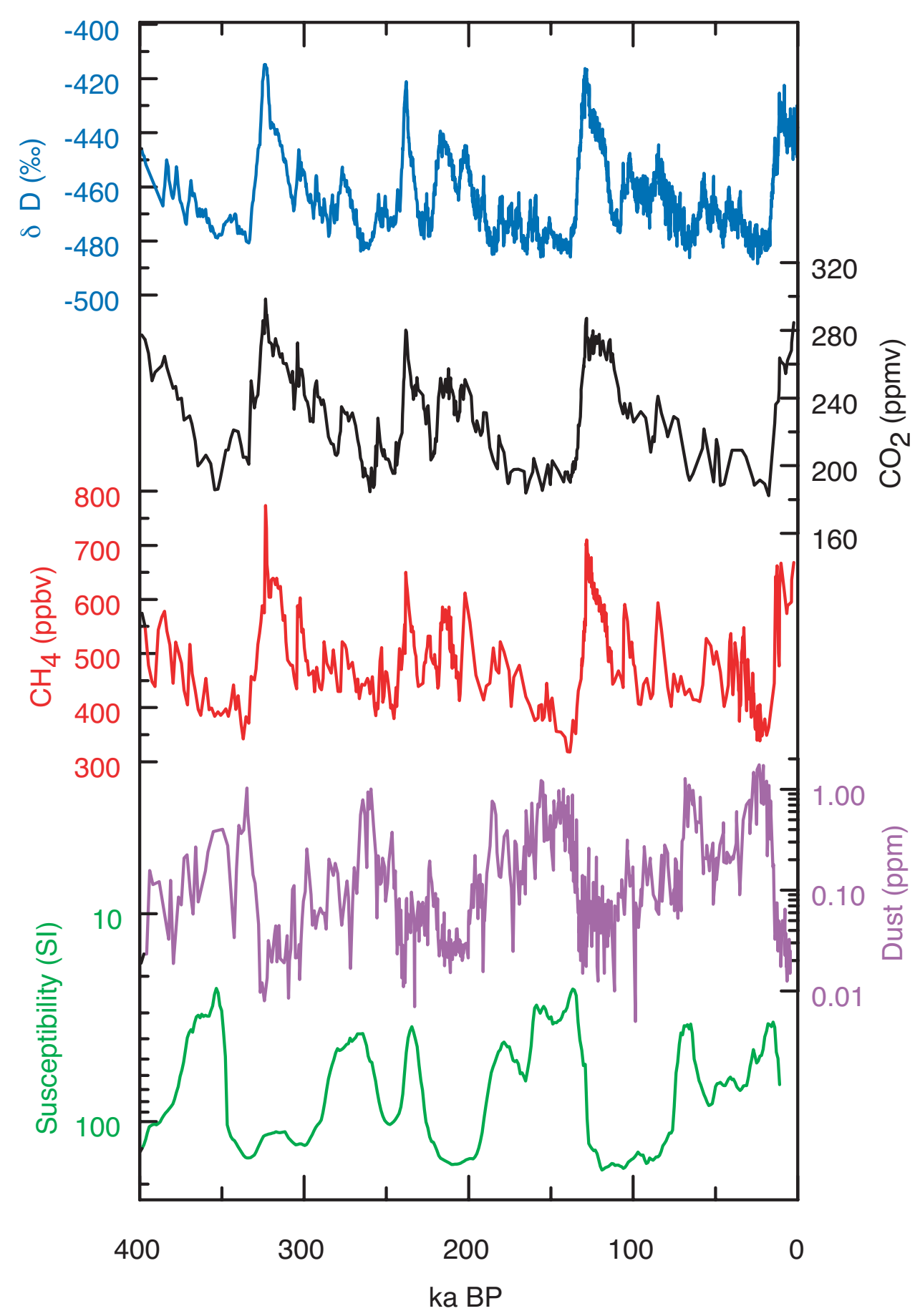

Fig. 2.2. Four climatic cycles. Climate records over the last 400,000 years. Deuterium, a proxy for local temperature, $\mathrm{CO}_{2}, \mathrm{CH}_{4}$ and dust (logarithmic scale) from the Vostok ice core (Petit et al. 1999, Pépin et al. in press). The Vostok dating is based on the glaciological time scale described in Petit et al. (1999). Below the Vostok records, the stacked low field magnetic susceptibility record (logarithmic scale) of the Chinese loess (Kukla et al. 1988) is plotted in SI units. The Chinese loess record has been obtained by averaging data from 2 different localities. The dating is established by considering the SPECMAP age for the last interglacial soil and the Bruhnes/Matuyama reversal taken at $780 \mathrm{kyr}$. The dating in-between has been interpolated. 
case with the increasing load of anthropogenic greenhouse trace gases. Results from different climate simulations make it reasonable to assume that these trace gases and their associated rapid feedbacks have contributed significantly (possibly about half, that is $2-3^{\circ} \mathrm{C}$ ) to the globally averaged glacialinterglacial temperature change (Berger et al. 1998, Weaver et al. 1998).

It is interesting to note that the $\mathrm{CO}_{2}$ increases associated with the four glacial-interglacial transitions start several thousand years before any intense deglaciation (Petit et al. 1999, Pépin et al. 2001). This observation leads to a sequence of climate forcings as follows: changing the orbital parameters initiated the glacial-interglacial climatic changes, then the greenhouse gases amplified the weak orbital signal, accompanied several thousand years later by the effect of decreasing albedo during the retreat of the Northern hemisphere ice sheets. The lag of continental ice volume changes to temperature and $\mathrm{CO}_{2}$ is also identified at the scale of the 100,000-year cycle (Shackleton 2000).

\subsubsection{Aerosols and DMS}

Atmospheric aerosol is an important component of the climatic system, but its role has not been investigated as much as that of greenhouse gases. In addition to temperature and gas records, ice core studies have provided information about the variations of atmospheric aerosol content under different climatic conditions in the past. Tropospheric and stratospheric primary and secondary aerosols (Section 2.1.2) have been documented.

Soil dust and sea salt emissions are one to two orders of magnitude higher than those of secondary aerosol. However, due to their very small size (generally $<1$ micron), gas-derived aerosols have a longer residence time in the air and are therefore able to be transported over larger distances than continental dust or sea spray. In central polar regions and under interglacial conditions, glaciochemical data indicate that sulfate aerosol generally dominates over primary aerosol (sea salt and continental dust) in the troposphere. In glacial periods, the situation is quite different.

Both Greenland and Antarctic ice cores show a remarkable increase in eolian dust supply during glacial periods (Thompson and Mosley-Thompson 1981, De Angelis et al. 1987, Petit et al. 1990, Mayewski et al. 1994, Mayewski et al. 1997). However, this effect is much more marked in Greenland than in Antarctic ice cores. In Greenland, dust deposited during glacial periods was alkaline and is associated with $\mathrm{Ca}^{++}$concentrations in the Last Glacial Maximum (LGM) ice that are about 50 times higher than the Holocene average (Fuhrer et al. 1993). Higher dust content in Greenland ice cores during glacial times can be explained by increased desert area in central Asia and a strengthening of the Asian winter monsoon. Biscaye et al. (1997) employed natural radioisotope measurements to show that this dust originates from Central Asia. Figure 2.2 illustrates the changing dust concentrations over 4 glacial cycles in Antarctica (Vostok) and the Chinese Loess Plateau. The fluctuations in these two records are similar. Note that the Vostok and Chinese time scales in Figure 2.2 are not synchronized and that dating uncertainties do not allow the establishment of the degree of synchroneity.

Kohfeld and Harrison (2000) have mapped the distribution of eolian dust accumulation rates at the LGM and mid-Holocene. Their study indicates that the dust deposition rate at LGM was approximately 2-5 times higher than at present, downwind of modern dust source areas. Their map illustrates the fact that most of the eolian dust in the world is concentrated in Asian and African monsoon areas.

The Asian Monsoon plays an especially important role in the transportation of eolian dust. The large eolian dust accumulation rates in Japan (Xiao et al. 1995, Ono and Naruse 1997) and the Japan Sea (Tada et al. 1999), downstream of both winter monsoon winds and the westerlies, support this idea. Electron spin resonance measurements on quartz grains suggest that the intensification of westerlies played an important role in the transportation of eolian dust from Central Asia to the Western Pacific during glacial periods (Ono et al. 1997). The reasons why eolian dust over Antarctica (at least in the Vostok and Dome $\mathrm{C}$ regions) was enhanced during glacial times is still uncertain. However, enlargement of desert area and outwash plains in Patagonia, strengthening of the southern westerlies, and the emergence of the continental shelf of Patagonia due to lower sea-level, as well as the dryness of the atmosphere (responsible for a less efficient removal of the aerosols), are all likely to have been involved (Delmonte et al. in press). Oba and Pederson (1999) estimated an eolian input of carbonates from the Asian continent to the Japan Sea at LGM, based on the age difference between bulk carbonates and mono-specific Foraminifera. Their measurements revealed a huge input of old carbonate by eolian transportation on the order of $100 \mu \mathrm{g} \mathrm{cm} \mathrm{yr}^{-1}$, which is about 2 orders of magnitude higher than that estimated for the NW Pacific.

The timing of the decline in dust accumulation in the Huascáran ice core, at the end of LGM (Figure 2.3), also correlates well with the decrease of organic carbon accumulation in the central Panama Basin (Pedersen and Bertrand 2000). 
Chinese loess provides one of the most complete records of the interplay between fluctuations in dust supply and climatic changes on glacial-interglacial time scales (e.g. Kukla et al. 1988, An and Porter 1997, An 2000). Loess deposition occurred more rapidly during glacials than interglacials (Ding et al. 1995, Porter and An 1995) and the grain size of loess deposited during glacials is coarser than in warmer periods (e.g. Ding et al. 1995, Porter and An 1995, Xiao et al. 1995, Lu et al. 1999, Xiao et al. 1999).

In glacial times, because of the weakening of the summer monsoon, the climate of Central and East Asia became dry. Pollen and fauna data indicate that the landscape changed to a more steppic or desertic one (Li et al. 1995). Not only the expanded desert, but also an emerged continental shelf due to lower sea level, enhanced the dust source area. The increased flux of finer sand and silt into dust source areas such as the Taklamakan desert, by fluvioglacial processes associated with the expansion of glaciers, provided an additional source of dust. The coarsening of Chinese loess grain size suggests a glacial increase in winter monsoon wind speeds as well (Xiao et al. 1995, Xiao et al. 1999). During the interglacials, a strengthened summer monsoon enhanced soil formation (pedogenesis), although the accumulation of loess continued (Fang 1995, Chen et al. 1997). This paleosol development in loess regions suggests vegetation cover (forest or steppe), more stable ground surface conditions and a much wetter climate due to enhanced summer monsoon rains. These landscape changes explain the decreased eolian dust supply from Central and East Asia during the interglacial periods.

Sulfur and nitrogen biogeochemical cycles, which are closely linked to environmental conditions, changed significantly during the ice age periods. Glaciochemical data from deep Greenland and Antarctic ice cores reflect these changes, in different ways, due to the different environmental conditions that prevailed in the northern and southern hemispheres during ice ages.

A major feature of the glacial ice at Vostok is its high content of continental dust and sea-salt aerosol as shown by the concentration patterns of insoluble dust particles (Petit et al. 1990), sodium and calcium (Legrand et al. 1988). This effect had been already pointed out some 10 years before at other polar sites (Cragin et al. 1977). The changes measured in ice depend on several factors (emission rates, meridional transport, atmospheric transformation and deposition mechanisms) which all may have changed in the past in relation to climate.

In the southern hemisphere, the atmospheric circulation has not been so dramatically modified as in the northern hemisphere. Most recent investigation (Basile et al. 1997) shows that over the last glacial and interglacial periods, the dominant source of dust for East Antarctica was always the southern part of South America. The geographical extent of this source was strongly modulated by sea-level changes. Despite the high inputs of crustal dust in glacial conditions, Vostok ice remained acidic during the study time periods (Legrand et al. 1988).

Concentrations of ions related to the major global sulfur and nitrogen cycles have been determined. Nitrate deposition in Vostok snow increased during glacial periods in parallel with crustal dust inputs (Legrand et al. 1988). Regarding the sulfur cycle, the authors concluded from ice core data that marine biogenic DMS emissions around Antarctica were enhanced during cold climatic stages (Legrand et al. 1991, Legrand et al. 1992), an assertion which needs further confirmation due to the postdepositional issues associated with MSA (see section 2.2.1).

\subsection{Abrupt climatic changes during the last ice age}

Superimposed on the large scale glacial-interglacial changes are climatic events known as DansgaardOeschger cycles, which occur with a frequency of 2-3 kyr and with amplitudes close to the glacialinterglacial changes themselves (see Chapter 3). These cycles affect large portions of the world and it is not surprising that they also have an effect on major trace gases (Figure 2.4).

\subsection{1 $\mathrm{CH}_{4}$ variations}

For the most part, $\mathrm{CH}_{4}$ concentrations change in concert with northern hemisphere temperature (Figure 2.4). Due to the age difference between reconstructed temperature and the gas signal from the same depth, it is not a priori clear which signal leads (Schwander et al. 1993). However, an innovative method based on thermal fractionation of nitrogen isotopes is able to answer this question for periods of fast temperature change (Lang et al. 1999, Severinghaus and Brook 1999). This method indicates that $\mathrm{CH}_{4}$ changes lag Greenland warming by up to a few decades at the last glacial termination and at the end of the Younger Dryas. This shows that $\mathrm{CH}_{4}$ changes are primarily a response to these abrupt northern climate changes rather than a driver. The $\mathrm{CH}_{4}$ signal recorded in polar ice cores is a global integration of sources and sinks. The $\mathrm{CH}_{4}$ sink is generally assumed to be fairly stable (Thompson 1992), suggesting that a major change of the $\mathrm{CH}_{4}$ source must be responsible for $\mathrm{CH}_{4}$ 


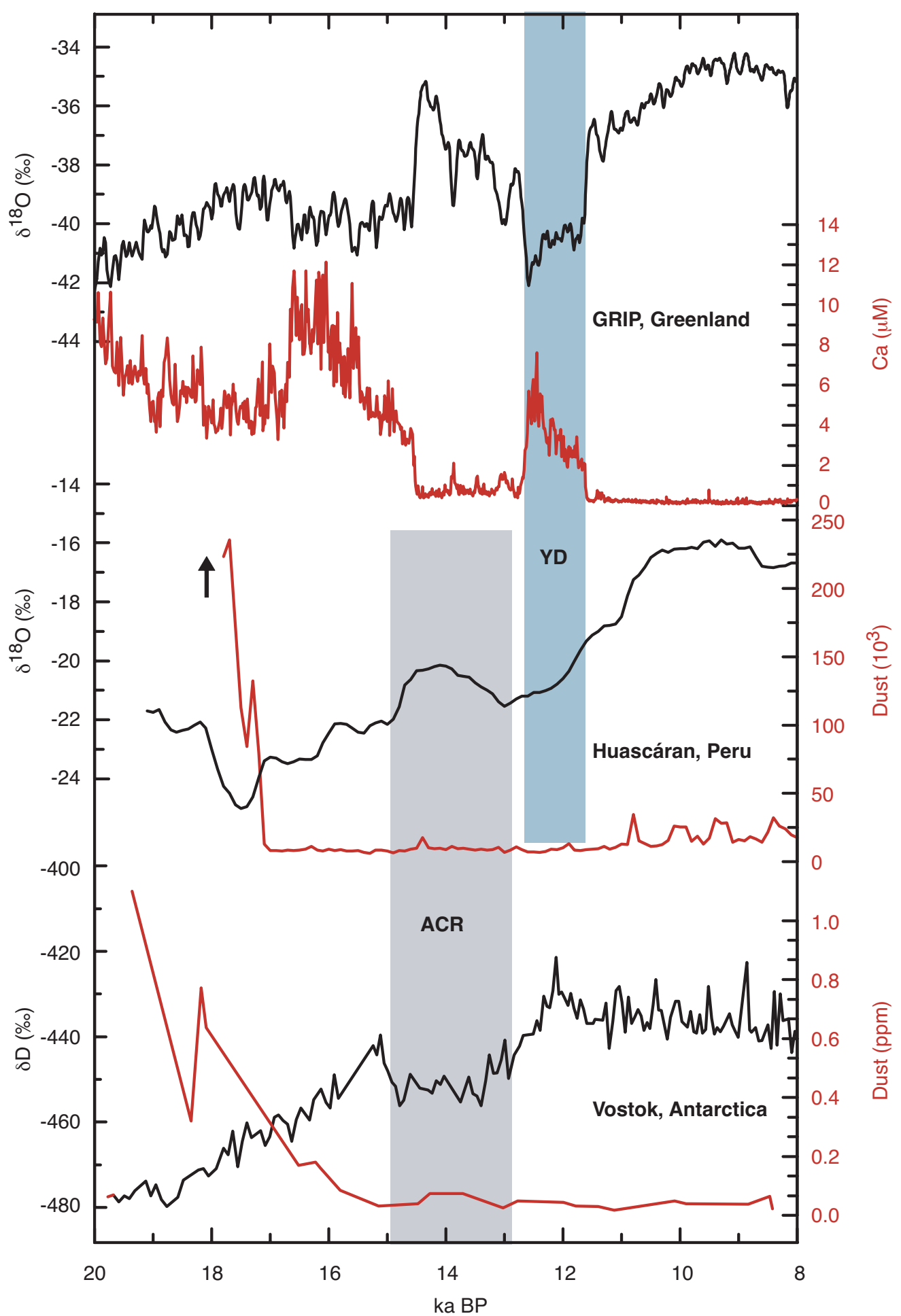

Fig. 2.3. Dust records over the last glacial-interglacial transition. Dust (solid red lines) and isotope records (solid black lines) from Greenland, Peru and Antarctica. Top: $\delta^{18} \mathrm{O}$ temperature (Dansgaard et al. 1993) and Ca (Fuhrer et al. 1993) record from the GRIP ice core. No continuous dust record exists for the central Greenland cores. However, $\mathrm{Ca}$ is considered to be representative of terrestrial dust (Fuhrer et al. 1993). Middle: $\delta^{18} \mathrm{O}$ and dust from Huascáran, Peru (Thompson et al. 1995) is plotted here on the time scale presented in Thompson (2000). Bottom: $\delta D$ and dust record from Vostok (Petit et al. 1999). The gray areas indicate the location of the Younger Dryas (YD) and the Antarctic Cold Reversal (ACR) for Greenland and Antarctica, respectively. 


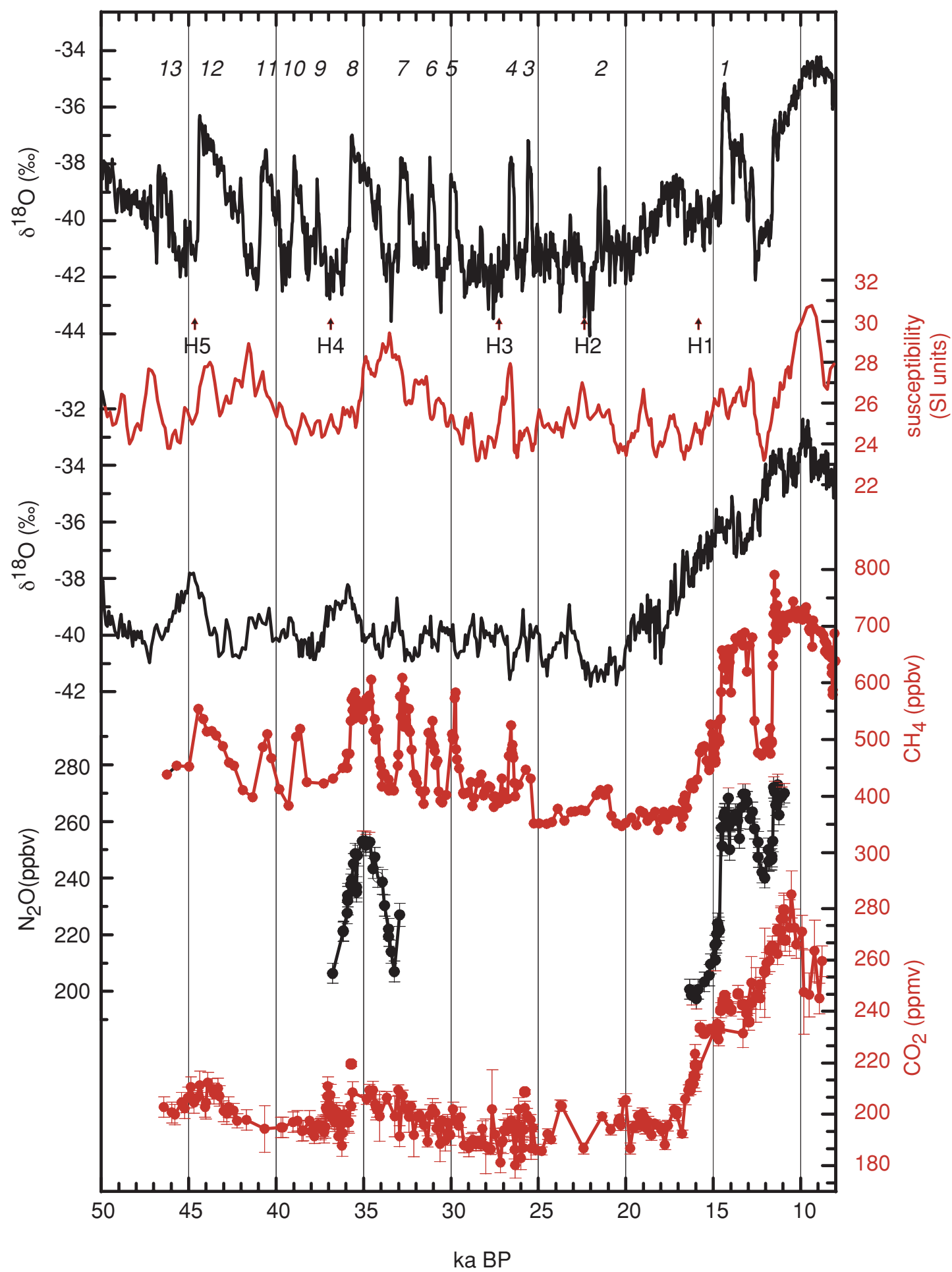

Fig. 2.4. Millennial scale changes. From top to bottom: Greenland (GRIP) oxygen isotopic record, a proxy for temperature (Dansgaard et al. 1993). Magnetic susceptibility from a Chinese loess record, a sensitive indicator of Asian summer monsoon (Fang et al. 1999). Antarctic (Byrd station) isotope record, a proxy for temperature (Johnsen et al. 1972). Methane record from Greenland (Blunier et al. 1993, Chappellaz et al. 1993, Dällenbach et al. 2000). $\mathrm{N}_{2} \mathrm{O}$ record from Greenland (Flückiger et al. 1999). $\mathrm{CO}_{2}$ record from Antarctica (Byrd station) (Stauffer et al. 1998, Marchal et al. 1999). Greenland and Antarctic records have been synchronized by using the global methane record (Blunier et al. 1998, Stauffer et al. 1998). Numbers 1-13 indicate Dansgaard-Oeschger events in the Greenland record. H1-H5 give the location of Heinrich events. 
concentration changes associated with rapid climate changes in the past. The major $\mathrm{CH}_{4}$ source under natural conditions is methanogenesis in wetlands. Large portions of high latitude present day $\mathrm{CH}_{4}$ wetland sources were covered under several kilometers of ice during the glacial. Thus, it is tempting to attribute rapid $\mathrm{CH}_{4}$ variations during the last glacial period and the transition following the Younger Dryas to variations in the low latitude wetland production. Records linked to monsoon activity in the Arabian region (Schulz et al. 1998) support this conjecture. However, recent reconstructions of the $\mathrm{CH}_{4}$ source distribution during D-O events and the last transition has given new insight into the cause of $\mathrm{CH}_{4}$ change (Brook et al. 2000, Dällenbach et al. 2000). This reconstruction is based on the bipolar $\mathrm{CH}_{4}$ difference between Greenland and Antarctica. It shows that $\mathrm{CH}_{4}$ changes associated with the transition from glacial to interglacial and the YD oscillation were indeed dominated by variability in tropical sources. However, mid to high latitude sources were already active during the Bølling-Allerød and did not decrease significantly during the YD cold period. According to Dällenbach et al. (2000), except during the coldest part of the last glacial period, high to mid latitude sources contributed significantly to the total $\mathrm{CH}_{4}$ budget, and even dominated the concentration changes during D-O events. One conclusion of this study is that atmospheric $\mathrm{CH}_{4}$ concentration during the last glacial is not an indicator of tropical precipitation, as has been suggested based on the concentration data from the Greenland site alone (Chappellaz et al. 1993). This implies that wetlands situated just south of the ice sheets were still active even under glacial climatic conditions.

In contrast to the fluctuations during the glacial, which seem to be primarily responding to changing northern hemispheric sources, the YD changes are associated with an emission change in the tropics (Brook et al. 2000, Dällenbach et al. 2000). This inference is supported by precipitation changes during the YD seen in lake level changes in Africa (Gasse 2000).

Recently, wetland emissions for the LGM and present day were modeled (Kaplan 2002). Kaplan's approach confirms in principle the results from the ice core approach but suggests that changes in wetland emissions are not fully responsible for the concentration change from glacial to interglacial.

An alternative explanation for rapid $\mathrm{CH}_{4}$ changes focuses on the enormous amount of $\mathrm{CH}_{4}$ stored in permafrost and continental margins in the form of hydrates (Nisbet 1990). Recently, Kennett et al. (2000) have shown that rapid climate change may be associated with the release of $\mathrm{CH}_{4}$ from hydrates in the Santa Barbara Basin (Kennett et al. 2000). However, it is likely that this source would not be able to maintain high concentration levels and that another source (likely wetlands) must be responsible for sustaining high atmospheric concentrations. Due to the diversity of the clathrate source it is difficult to estimate its potential influence. An answer as to whether or not clathrates release is important during rapid climate change events may come from measurements of the $\delta^{13} \mathrm{C}$ and $\delta \mathrm{D}$ signature of $\mathrm{CH}_{4}$.

\subsection{2 $\mathrm{N}_{2} \mathrm{O}$ variations}

The $\mathrm{N}_{2} \mathrm{O}$ record is not as complete as the $\mathrm{CH}_{4}$ record (Figure 2.4). Currently available $\mathrm{N}_{2} \mathrm{O}$ records span one D-O event, the transition from the last glacial to the Holocene, the Holocene (Figure 2.5) (Flückiger et al. 1999, Flückiger et al. 2001) and the penultimate deglaciation (Sowers 2001). Some particularly high concentrations were found over very short core sections in a Greenland core. Elevated values were also found over the penultimate deglaciation in the Vostok core (Sowers 2001). Besides bacterial alteration, a chemical reaction in the ice was suggested for these higher values (Flückiger et al. 1999, Sowers 2001).

The undisturbed part of the $\mathrm{N}_{2} \mathrm{O}$ record covaries, like $\mathrm{CH}_{4}$, largely with Greenland temperature and thus seems to be related to climate changes in the northern hemisphere. Within this general pattern of agreement, differences between the $\delta^{18} \mathrm{O}$ and the $\mathrm{CH}_{4}$ records do exist. During the Bølling-Allerød and D-O event 8 the $\mathrm{CH}_{4}$ concentration reaches its high interstadial level simultaneously with the $\delta^{18} \mathrm{O}$ inferred temperature maximum. The $\mathrm{N}_{2} \mathrm{O}$ concentration maximum, on the other hand, lags by several hundred years. The decrease in $\mathrm{N}_{2} \mathrm{O}$ concentration at the end of warmer epochs starts at the same time or even before decreases in $\delta^{18} \mathrm{O}$ and $\mathrm{CH}_{4}$, but the lowest $\mathrm{N}_{2} \mathrm{O}$ concentrations occur about 500 years after the minimum $\delta^{18} \mathrm{O}$ values and about 300 years after minimum $\mathrm{CH}_{4}$ concentrations. This delay of the $\mathrm{N}_{2} \mathrm{O}$ decrease is not explained by the longer lifetime of $\mathrm{N}_{2} \mathrm{O}$ as compared to $\mathrm{CH}_{4}$. Assuming that the sink of $\mathrm{N}_{2} \mathrm{O}$, photodissociation in the stratosphere, did not vary significantly in the past, $\mathrm{N}_{2} \mathrm{O}$ sources must have decreased slowlier after a climatic cooling than did those of $\mathrm{CH}_{4}$. Unlike $\mathrm{CH}_{4}$, $\mathrm{N}_{2} \mathrm{O}$ does not decrease to near glacial levels during the YD. This has been attributed to different changes in the strength and nature of their respective sources. While $\mathrm{CH}_{4}$ sources were reduced to close to late glacial levels during the $\mathrm{YD}, \mathrm{N}_{2} \mathrm{O}$ sources declined by less than $40 \%$ of the full glacial-interglacial difference (Flückiger et al. 1999). 


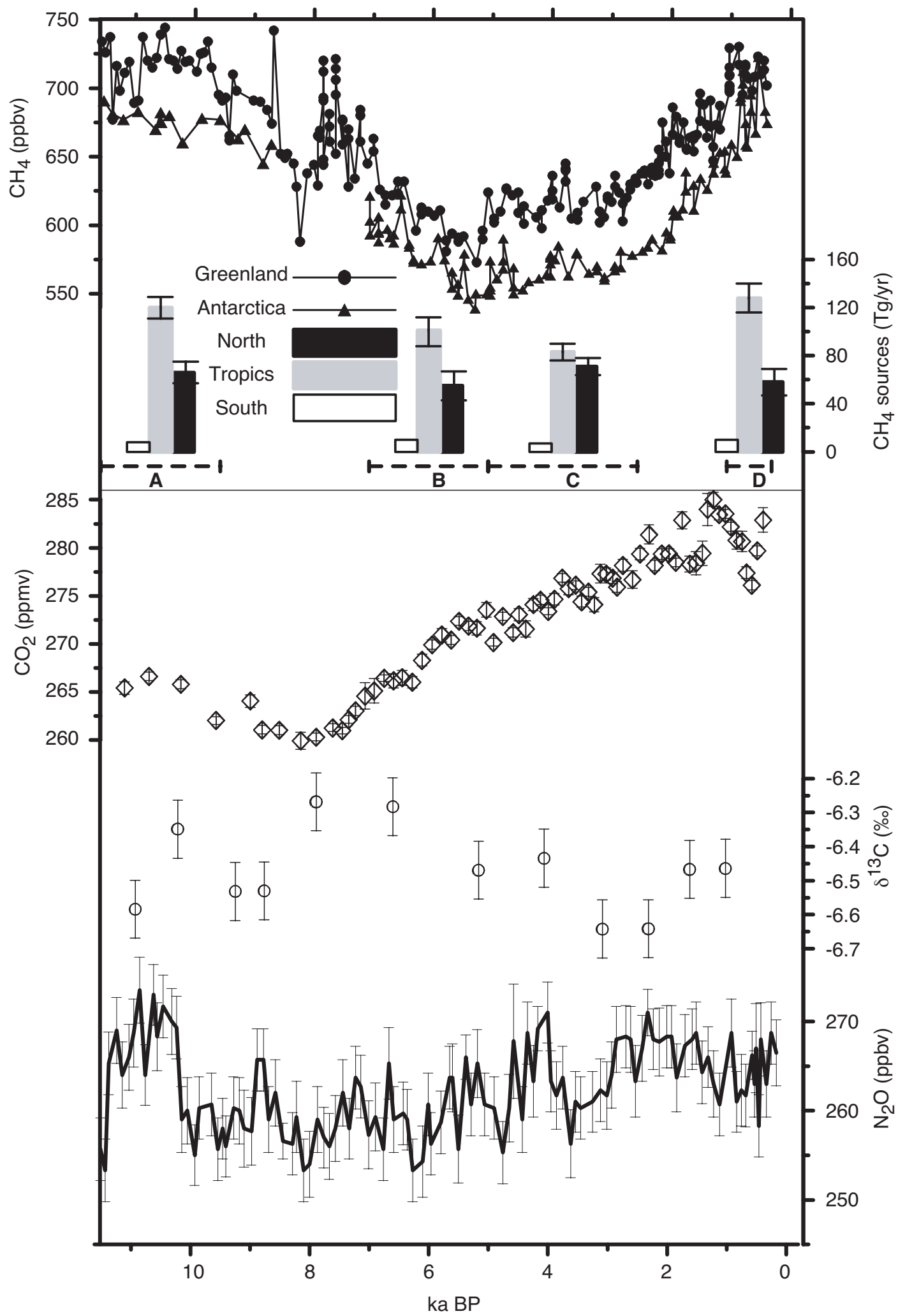

Fig. 2.5. Holocene records. Top: $\mathrm{CH}_{4}$ records from Greenland (dots) and Antarctica (triangles) with budget calculations for latitudinal bands (Chappellaz et al. 1997). Calculations have been made with a box model. Boxes span from $90^{\circ} \mathrm{N}-30^{\circ} \mathrm{N}, 30^{\circ} \mathrm{N}-$ $30^{\circ} \mathrm{S}$ and $30^{\circ} \mathrm{S}-90^{\circ} \mathrm{N}$. Middle: $\mathrm{CO}_{2}$ and $\delta^{13} \mathrm{C}$ record from Taylor Dome Antarctica (Indermühle et al. 1999). Bottom: $\mathrm{N}_{2} \mathrm{O}$ record from Dome C (EPICA project) (Flückiger et al. 2001). 
Other than $\mathrm{CH}_{4}$, whose sources are almost entirely on land, $\mathrm{N}_{2} \mathrm{O}$ has both oceanic and terrestrial sources. On land, $\mathrm{N}_{2} \mathrm{O}$ is produced in soils. The process depends mainly on the input of nutrients, moisture status, temperature and level of oxygenation. The size of the oceanic $\mathrm{N}_{2} \mathrm{O}$ source depends not only on the rates of $\mathrm{N}_{2} \mathrm{O}$ production in situ, but also on gas transfer rate from the depth of production to the surface. Climate changes can influence both sources but their individual contributions, and even the sign of their responses, are difficult to estimate. As both oceanic and terrestrial sources are able to change rapidly, even well constrained estimates of the rate of $\mathrm{N}_{2} \mathrm{O}$ increase (e.g. from the last glacial to the Bølling-Allerød) are not sufficient to differentiate the sources. Thus, currently available data do not yet allow us to infer the sources responsible for $\mathrm{N}_{2} \mathrm{O}$ concentration changes seen in the paleorecord.

\subsection{3 $\mathrm{CO}_{2}$ variations}

Measurements of the $\mathrm{CO}_{2}$ concentrations in the air bubbles entrapped in ice cores from Greenland reveal large $\mathrm{CO}_{2}$ variations associated with $\mathrm{D}-\mathrm{O}$ events. Levels of 200 and 250 ppmv predominate during the cold and warm phases of the last glacial, respectively (Stauffer et al. 1984). However, measurements on Antarctic ice cores do not show variations of this magnitude (Neftel et al. 1988, Oeschger et al. 1989, Indermühle et al. 2000). It is now believed that the high $\mathrm{CO}_{2}$ concentrations during warm phases in the Greenland ice cores do not represent the atmospheric concentration but are a spurious signal caused by an acid-carbonate reaction or by oxidation of organic material in the ice (Delmas 1993, Anklin et al. 1995, Tschumi and Stauffer 2000). In situ production of $\mathrm{CO}_{2}$ in Antarctica can not completely be ruled out, but it is thought to be small.

The high-resolution record of the atmospheric $\mathrm{CO}_{2}$ concentration from the Taylor Dome ice core contains four distinct millennial scale peaks of 20 ppmv during the period from 60 to $20 \mathrm{kyr} \mathrm{BP}$ (Figure 2.4). These long-term $\mathrm{CO}_{2}$ variations correlate with Antarctic temperature reconstructions based on stable isotope measurements on the Vostok ice core (Indermühle et al. 2000). Strong D-O events in the northern hemisphere are preceded by a warming in Antarctica (Blunier and Brook 2001). The southern hemisphere warming, and apparently also the atmospheric $\mathrm{CO}_{2}$ concentration increase, occur when Greenland temperatures are lowest (Indermühle et al. 2000). Possible mechanisms for this asynchronous behavior are discussed in Chapter 3 .

Recently, a high resolution record from Dome C has confirmed and provided further details that expand on earlier measurements from Antarctica over the last glacial termination (Monnin et al. 2001). It is now clear that the Antarctic temperature rise started at least 200 years before the beginning of the $\mathrm{CO}_{2}$ increase. The $\mathrm{CO}_{2}$ concentration increases in stages from glacial to interglacial level over the termination. These stages can be compared best to the $\mathrm{CH}_{4}$ signal which is also a first order approximation for northern hemispheric temperature changes over this period. Surprisingly, the steps in $\mathrm{CO}_{2}$ and $\mathrm{CH}_{4}$ concentration changes are identical, pointing to a northern hemispheric influence on the $\mathrm{CO}_{2}$ increase. A first $\mathrm{CO}_{2}$ increase of about 35 ppmv happens during a first moderate increase of the $\mathrm{CH}_{4}$ concentration from about 17-15.5 kyr BP. Over a section of $\sim 15.5$ to 14 where the $\mathrm{CH}_{4}$ concentration is roughly constant $\mathrm{CO}_{2}$ increases slowly. At the sharp $\mathrm{CH}_{4}$ increase, which parallels the sharp Greenland temperature increase into the BøllingAllerød period, $\mathrm{CO}_{2}$ rises almost instantaneously by about 10 ppmv. $\mathrm{CO}_{2}$ slightly decreases over the Bølling-Allerød period, which roughly corresponds to the Antarctic Cold Reversal, to finally increase by $30 \mathrm{ppmv}$ over the YD period to its Holocene level. The general shape of the $\mathrm{CO}_{2}$ increase corresponds to the Antarctic isotope record, pointing to a southern ocean explanation for the increase. However, the details of the $\mathrm{CO}_{2}$ increase have some characteristics of the northern hemispheric climate change, pointing to a non-negligible northern hemispheric influence on the global carbon cycle at least over the last termination. The northern hemispheric influence presumably reflects changes in the north Atlantic deep water formation (Marchal et al. 1999).

\subsubsection{Dust}

Eolian dust shows a remarkable response to the abrupt climatic changes during the last glacialinterglacial transition and during the last glacial period (Figure 2.3). A rapid increase of eolian dust in Greenland cores during the Younger Dryas, for example, is interpreted as the result of increased wind speed (Alley 2000). Further back in the last ice age, the chemical records in Greenland ice cores show that dust content is clearly connected to D-O rapid events (Fuhrer et al. 1993).

Changes in the rates of deposition of eolian dust during D-O cycles and Heinrich Events have also been reported in Chinese loess (Figure 2.4) (Porter and An 1995, Chen et al. 1997, Fang et al. 1999) and in marine records from the Arabian (Leuschner and Sirocko 2000), South China (Wang et al. 1998) and Japan Seas (Tada et al. 1999).

The highest resolution records in Chinese loess 
(100-200 year resolution) capture millennial-scale variability which may reflect the rapid alternation of summer and winter monsoon systems (Figure 2.3), perhaps linked to changes in the westerlies (Guo et al. 1996, Guo et al. 1998). During warmer interstadial periods, the westerlies were situated in the north of the Tibetan Plateau, as in the modern summer, but during colder periods they were located south of the Himalaya for the entire year, as in the present winter (Fang et al. 1999). Marine records from the Japan Sea and the South China Sea suggest that interactions between the westerlies and monsoons are correlated with sudden warming and cooling in the North Atlantic (Wang and Oba 1998, Tada et al. 1999, Wang et al. 2001). A satisfactory dynamical explanation has yet to be proposed for the apparent correlation of continental and marine Asian dust records with climate in the North Atlantic. A fuller understanding of these connections is likely to require higher resolution records.

\subsection{The Holocene}

Studying the Holocene is of special interest for documenting the interactions between climate and biogeochemical cycles under climatic conditions close to those prevailing today. These interactions provide insight into feedback processes relevant to understanding changes that are expected to occur in the near future. Thus, the study of the Holocene provides information about the sensitivity of atmospheric trace gas concentrations to latitudinal changes in different climatic forcing such as insolation.

Figure 2.5 shows trace gas concentrations of $\mathrm{CH}_{4}$, $\mathrm{CO}_{2}$ and $\mathrm{N}_{2} \mathrm{O}$ over the Holocene period. Late glacial and early Holocene dust variations from Greenland, tropical South America and Antarctica are shown in Figure 2.3.

\subsection{1 $\mathrm{CH}_{4}$ variation over the Holocene}

High resolution $\mathrm{CH}_{4}$ data are available for the entire Holocene (Blunier et al. 1995, Chappellaz et al. 1997). Results have been obtained from two Antarctic ice cores (D47 and Byrd) and a Greenland core (GRIP). The concentrations obtained from the southern cores are systematically lower than those from the northern cores (Figure 2.5). This latitudinal difference in concentration reflects the heterogeneous latitudinal distribution of $\mathrm{CH}_{4}$ sources and sinks and the fact that the atmospheric residence-time is only one order of magnitude longer than the interhemispheric exchange time.

The main atmospheric sink of $\mathrm{CH}_{4}$ is oxidation by the $\mathrm{OH}$ radical. The only means currently available to investigate the past strength of this sink is through photochemical model studies (see for instance Thompson 1992, Crutzen and Brühl 1993, Thompson et al. 1993, Martinerie et al. 1995). All models suggest that $\mathrm{OH}$ concentrations were 10$30 \%$ higher just prior to industrialization and also only slightly higher in the glacial period. Thus, the primary reason for past $\mathrm{CH}_{4}$ concentration changes is probably variation in the sources. The largest preindustrial source was wetlands, which constituted over $70 \%$ of the total source (Houghton et al. 1995). Other sources, such as termites, wild animals, wildfires, oceans and $\mathrm{CH}_{4}$ hydrates in permafrost and continental shelves are a relatively minor source.

An average difference of $44 \pm 4$ ppbv occurred during the early Holocene (11.5 to $9.5 \mathrm{kyr} \mathrm{BP})$. The minimum bipolar gradient, a difference of $33 \pm 7$ ppbv, occurred from 7 to $5 \mathrm{kyr}$ BP whereas the maximum gradient $(50 \pm 3 \mathrm{ppbv})$ took place from 5 to $2.5 \mathrm{kyr}$ BP (Chappellaz et al. 1997).

Using the $\mathrm{CH}_{4}$ mixing ratio distribution inferred from the polar ice cores together with a box model, Chappellaz et al. 1997 inferred the time-varying strength of Holocene $\mathrm{CH}_{4}$ sources in the tropics $\left(30^{\circ} \mathrm{S}-30^{\circ} \mathrm{N}\right)$ and the mid to high latitudes of the northern hemisphere $\left(30-90^{\circ} \mathrm{N}\right)$. The model inferred source histories are shown in Figure 2.5. The model indicates that Holocene $\mathrm{CH}_{4}$ variations were predominantly driven by changes in tropical sources, together with some minor modulations from boreal sources. The large early Holocene tropical source was most likely due to increased wetland extent accompanying what is reconstructed as the wettest period of the Holocene in the Tropics (Petit-Maire et al. 1991, Street-Perrott 1992). During the periods from 7-5 and 5-2.5 kyr BP, continual drying of the tropical regions is thought to have taken place. This is consistent with the inferred reduction in terrestrial $\mathrm{CH}_{4}$ sources during this period. In boreal regions massive peat growth began in the mid-Holocene (Gorham 1991, Vardy et al. 2000). Surprisingly, however, the high latitude methane source strength does not appear to have increased substantially during the Holocene. It is possible that the increase in boreal wetlands comprised a northward shift of pre-existing wetland regions rather than the creation of net wetland area.

The period from 1-0.25 kyr BP is marked by a small $\mathrm{CH}_{4}$ gradient and a high absolute level. The model infers from these observations a major tropical source over this period. As pointed out above, the wetland areas of North Africa experienced continuous drying from the mid Holocene until today. Therefore the inferred low latitude $\mathrm{CH}_{4}$ source increase of the last millennium may reflect either local increase in wetness or early anthropogenic 
contributions to the $\mathrm{CH}_{4}$ budget (Kammen and Marino 1993, Subak 1994).

\subsection{2 $\mathrm{CO}_{2}$ increase over the Holocene}

The Antarctic Taylor Dome $\mathrm{CO}_{2}$ and $\delta^{13} \mathrm{C}$ records (Indermühle et al. 1999) (Figure 2.5) have recently revealed that the global carbon cycle has not been in steady state during the Holocene (Figure 2.5). The records show an 8 ppmv decrease in the $\mathrm{CO}_{2}$ mixing ratio and a $0.3 \%$ increase in $\delta^{13} \mathrm{C}$ between 10.5 and $8.2 \mathrm{kyr} \mathrm{BP}$, and then over the following $7 \mathrm{kyr}$ a fairly linear 25 ppmv $\mathrm{CO}_{2}$ increase accompanied by a $\sim 0.2 \% \circ \delta^{13} \mathrm{C}$ decrease (Figure 2.5). Inverse methods based on a one-dimensional carbon cycle model applied to the Taylor Dome record (Indermühle et al. 1999) suggest that changes in terrestrial biomass and sea surface temperature are primarily responsible for the observed $\mathrm{CO}_{2}$ changes. In particular, the $\mathrm{CO}_{2}$ increase from 7 to $1 \mathrm{kyr} \mathrm{BP}$ could correspond to a cumulative continental biospheric release of about $195 \mathrm{GtC}$, in connection with a change from warmer and wetter mid-Holocene climate to colder and drier pre-industrial conditions. This model result is not sensitive to surface-to-deep ocean mixing and air-sea exchange coefficients because of their faster time scales. Changes in the biological carbon isotope fractionation factor, which varies according to the contribution from $\mathrm{C} 3$ and $\mathrm{C} 4$ plants due to environmental changes, may contribute up to $30-50 \%$ of the observed and modeled changes. The resulting additional uncertainty in the cumulative biospheric carbon release is $\pm 30 \mathrm{GtC}$ at $7 \mathrm{kyr} \mathrm{BP}$ and $\pm 70 \mathrm{GtC}$ at $1 \mathrm{kyr} \mathrm{BP}$.

\subsubsection{The Holocene $\mathrm{N}_{2} \mathrm{O}$ level}

Nitrous oxide concentrations are relatively stable in the Holocene with a mean value of $265 \mathrm{ppbv}$ and variations in the order of \pm 10 ppbv (Figure 2.5) (Flückiger et al. 2001). These small variations can be explained by source variations of less than $5 \%$. Whether these variations were due to oceanic or terrestrial sources and in what way they may have been related to climatic changes remains an open question that might be answered with the help of isotope analyses of $\mathrm{N}_{2} \mathrm{O}$.

\subsubsection{Dust}

Natural aerosol supply decreased drastically after the LGM due to shrinking desert area, vegetation growth, and lower wind speeds (Figure 2.4). Holocene dust concentrations, as recorded in the Huascáran ice core, were more than two orders of magnitude lower than glacial levels. The variability in Holocene dust concentration was also small compared to glacial times (Thompson et al. 1995) and is characterized by much more subtle century and millennial scale variability. The $\mathrm{CH}_{4}$ and $\mathrm{CO}_{2}$ variations observed during the Holocene confirm that the latitudinal distribution of continental ecosystems and the hydrological cycle experienced significant changes during this period, which is also revealed by continental proxies. It should be noted that anthropogenic land use may have already begun to influence dust concentrations prior to the industrial revolution.

More recently, millennial-scale oscillations have been observed in Antarctic ice (Delmonte et al. in press). The results indicate that the important property, in this case, is the variation in dust size distribution, which reflects the intensity of the atmospheric circulation over Antarctica.

\subsection{The last millennium}

\subsubsection{Greenhouse gases}

Trace gas concentrations varied little over the preindustrial period of the last millennium (Figure 2.6). For $\mathrm{N}_{2} \mathrm{O}$, the precision of the data is not sufficient to interpret small natural changes during the last millennium. The $\mathrm{CO}_{2}$ record suggest slightly increased concentrations from $\sim \mathrm{AD} 1200-1400$, during Medieval times, and slightly reduced concentrations from $\sim \mathrm{AD} 1550-1800$, during the Little Ice Age. However, caution should be used in interpreting these variations as natural. Although all ice core records show generally the same picture, it is possible that a small contribution from chemical reactions in the ice has caused these variations (Barnola 1999).

The $\mathrm{CH}_{4}$ variations appear to parallel the main climatic features during this period. $\mathrm{High} \mathrm{CH}_{4}$ concentration at the end of the $12^{\text {th }}$ century corresponds to warmer conditions in many regions (see Chapter 6, section 6.5) and a decrease in $\mathrm{CH}_{4}$ concentration correlates with the subsequent Little Ice Age. Variations in the oxidizing capacity of the atmosphere can only explain a minor part of pre-industrial fluctuations; the main contribution must stem from changes in methane emissions (Blunier et al. 1993). Climatic fluctuations on this time scale probably influenced the largest natural sources, i.e. wetlands, but the lack of climate proxy data on a global scale precludes a quantitative estimate of this effect. The role of pre-industrial anthropogenic sources may have been significant before the major population growth (Kammen and Marino 1993, Subak 1994) but it cannot account for the full amplitude of $\mathrm{CH}_{4}$ variations.

Ice-based gas records do not reach to the present, due to the occlusion process. Continuous instrumental records of the atmospheric concentration of 


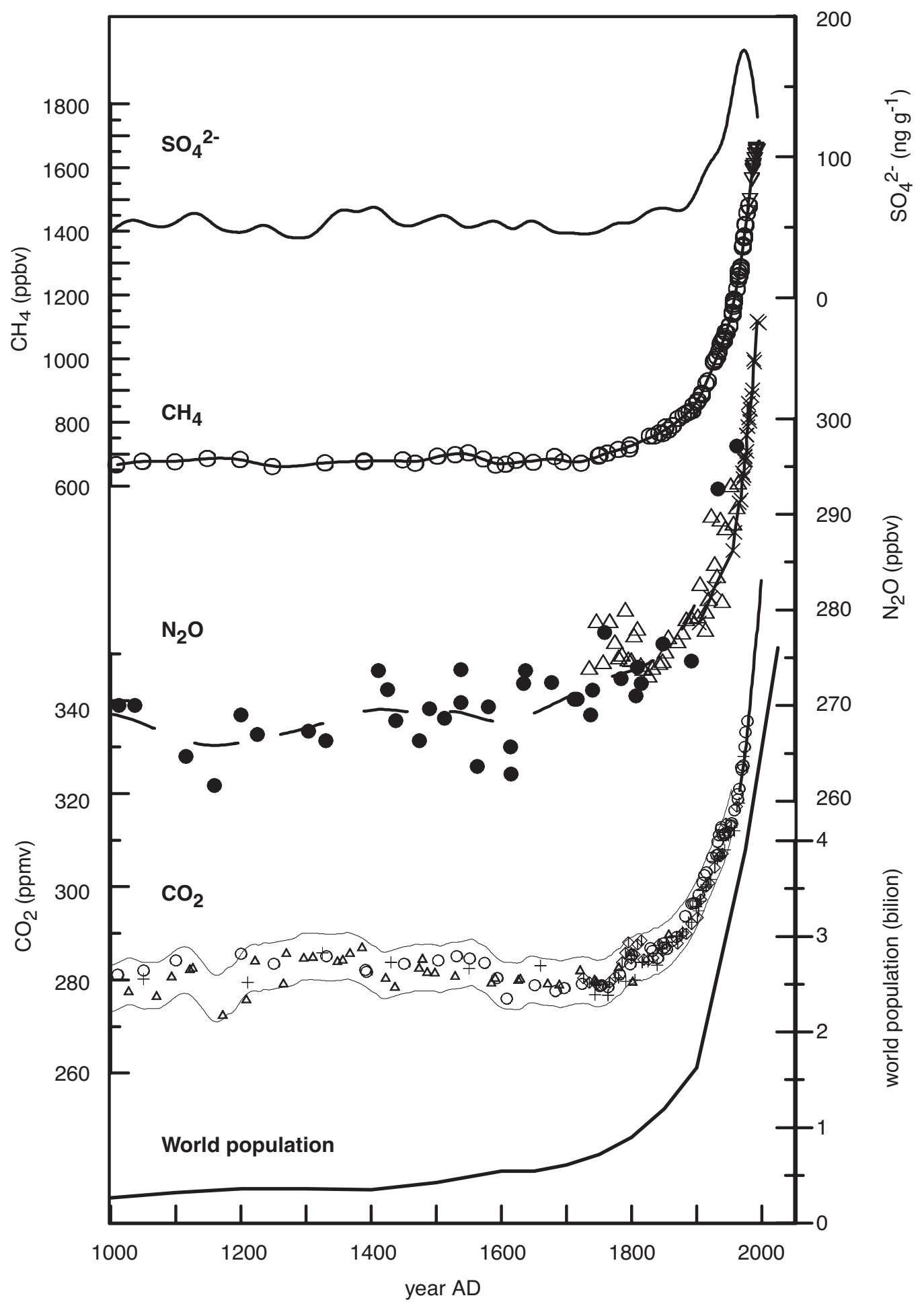

Fig. 2.6. Records over the last millennium. Sulfate record from Greenland (Bigler et al. in press). $\mathrm{CH}_{4}$ record from Law Dome, Antarctica, including firn measurements (open circles) and direct atmospheric measurements (open triangles) from Cape Grim, Tasmania (Etheridge et al. 1998). $\mathrm{N}_{2} \mathrm{O}$ measurements from ice cores (Machida et al. 1995, Flückiger et al. 1999) and firn air (Battle et al. 1996). $\mathrm{CO}_{2}$ data from Antarctic ice cores compiled by Barnola (1999). The ice core measurements overlap with direct atmospheric measurements (solid line) (Keeling and Whorf 2000). World population (McEvedy and Jones 1979). 
the most important trace gases start in 1958 for $\mathrm{CO}_{2}$ (Keeling et al. 1989), and 1978 for $\mathrm{CH}_{4}$ and $\mathrm{N}_{2} \mathrm{O}$ (Blake and Rowland 1987, Prinn et al. 1990). Subsequently, a relatively dense monitoring network has been established which allows observation not only of the ongoing anthropogenic increase in these gas concentrations, but also of annual variations of the atmospheric mixing ratio as a function of latitude. The link between atmospheric data and data from ice cores can be made by concentration measurements on the firn air. The evolution of $\mathrm{CO}_{2}, \mathrm{CH}_{4}$ and $\mathrm{N}_{2} \mathrm{O}$ from ice, firn and atmospheric records over the last millennium is shown alongside world population growth in Figure 2.6.

A continuous record of $\mathrm{CO}_{2}$ over the past millennium which overlaps with the period of instrumental data is contained in the Law Dome ice core (Etheridge et al. 1996). It is beyond doubt that the atmospheric $\mathrm{CO}_{2}$ concentration has been increasing since the industrial revolution, reaching a level unprecedented over more than 400,000 years. The pre-anthropogenic level of $\mathrm{CO}_{2}$ during the last millennium is approximately $200 \pm 10 \mathrm{ppmv}$ (Etheridge et al. 1996).

$\mathrm{CH}_{4}$ concentrations have been measured in several ice cores by several laboratories for changes during the last millennium (Craig and Chou 1982, Khalil and Rasmussen 1982, Rasmussen and Khalil 1984, Stauffer et al. 1985, Pearman et al. 1986, Etheridge and Pearman 1988, Etheridge et al. 1992, Dibb et al. 1993, Nakazawa et al. 1993, Etheridge et al. 1998). All these records show an increase during the last 200 years from a global mean value of about 700 ppbv to about 1700 ppbv today. This increase parallels remarkably well the human population increase (Figure 2.6). The main reason for the $\mathrm{CH}_{4}$ concentration increase is the increase from sources associated with population growth, such as domestic ruminants, rice paddies, biomass burning, landfills, and fossil fuel exploitation (Fung et al. 1991). Models suggest that about $20 \%$ of the $\mathrm{CH}_{4}$ increase over the last millennium reflects a relative decline in oxidation by hydroxyl ion concentration (Thompson 1992).

$\mathrm{N}_{2} \mathrm{O}$ measurements in ice started later than those of $\mathrm{CO}_{2}$ and $\mathrm{CH}_{4}$. Although early measurements had high scatter, measurement and extraction techniques have been improved in recent years. Ice core data indicate a pre-industrial mean value of $270 \pm 5 \mathrm{ppbv}$ (Flückiger et al. 1999) compared to an atmospheric concentration of 314 ppbv in 1998 (Houghton et al. 2001). This $\mathrm{N}_{2} \mathrm{O}$ increase is again closely correlated to the world population increase (Figure 2.6). Both natural and anthropogenic sources are primarily biogenic. $\mathrm{N}_{2} \mathrm{O}$ increases are due to the increase in agricultural area and changing agricultural cultiva- tion processes such as the introduction of legumes in crop rotation and the use of animal manure (Kroeze et al. 1999). A fraction of the increase may be derived from a progressive increase in denitrification in coastal waters in some regions (Naqvi and Jayakumar 2000).

\subsubsection{Aerosols}

\section{Pre-industrial}

Changes in the atmospheric aerosol load during the last millennium are documented by historical and ice core records. Prior to industrialization, soot was generated by forest fires and agricultural biomass burning. Land use changes involving extensive deforestation and development of dry field agriculture led to increases in aerosol input from the land surface. One of the largest recorded historical agriculture and drought-induced aerosol supply events was the dust bowl of the 1930s in the western USA. A rapid aerosol increase during the $16^{\text {th }}$ century recorded in the Quelccaya Ice Cap, Peru, is interpreted to be the result of agricultural development by the Incas in the Andes (Thompson et al. 1988). The Little Ice Age is also characterized by elevated dust concentrations in several ice cores (MosleyThompson et al. 1993, Thompson 1995). The Chinese historical record of dust fall also indicates increased dust supply during the Little Ice Age, in the intervals from 1621 to 1700 , and 1811 to 1900 (Zhang 1984). This historical record is interpreted as a proxy for dust storm frequency in the desert areas of western China.

Large volcanic eruptions also provide abrupt and intense periods of increased primary (ash) and secondary (sulfuric acid) aerosol concentrations in the atmosphere. The deposits from past cataclysmic eruptions, including many precisely dated by documentary records, are well preserved in polar ice cores and easily detected by ice electrical conductivity measurements (ECM). The climatic effect of these volcanic aerosols is hemispheric to global scale cooling lasting for one to several years. Temperature reconstructions from tree rings indicate a northern hemispheric cooling of 0.3 to $0.8^{\circ} \mathrm{C}$ correlating with volcanic eruptions (Briffa et al. 1998).

\section{Anthropogenic increase}

The concentrations of sulfate aerosols over the past 1000 years is recorded in several ice cores. In Figure 2.6 we show an example from Greenland. Contrary to the trend of long-lived greenhouse gases, which are nearly evenly distributed over the globe, the sulfate trend is only valid on the regional scale due to the relatively short residence time of sulfurspecies in the atmosphere. 
Anthropogenic $\mathrm{SO}_{3}$ and $\mathrm{NO}_{2}$ gas emissions have drastically increased the total number of aerosols in the atmosphere as compared to earlier Holocene times. Today, most aerosol particles, at least in the northern hemisphere, are derived from coal and oil burning in populated areas. Unlike agricultural dust, which is made of soil particles, industrial aerosol is largely composed of compounds of sulfate and nitrate. These gas-derived particles are transported by wind throughout the hemisphere into Arctic areas, far away from their source regions. Sulfate, nitrate and acidity measurements in ice cores demonstrate the rapid increase of industrial aerosols over the past two centuries, but this trend is presently confined to the northern hemisphere.

\subsection{Conclusions, a view in the context of future changes}

We are well aware that the past will not provide a precise analogue of the future, but it provides lessons to be learned from real experiments that the earth-climate system has undergone. Thus the paleo-record shows how the system reacts under different climatic conditions. Furthermore it provides the context for the dramatic change in atmospheric composition induced by the growing anthropogenic perturbation over the last 200 years. In the case of greenhouse trace gases the record impressively demonstrates that present-day atmospheric concentrations are unprecedented for over $\sim 400,000$ years.

The $\mathrm{CO}_{2}$ and $\delta^{13} \mathrm{C}$ ice-core records provide important boundary conditions and constraints for carbon models (oceanic and biospheric) used to estimate the uptake of anthropogenic carbon by terrestrial and oceanic sinks. The Holocene results point out the potential of past $\mathrm{CO}_{2}$ and $\delta^{13} \mathrm{C}$ records (when used in inverse modeling) to provide further constraints on the global carbon budget under different climatic conditions and to provide tests for climate models intended to simulate future responses to increasing concentrations in greenhouse gases.
More resolved $\mathrm{CO}_{2}$ and $\mathrm{N}_{2} \mathrm{O}$ isotopic records are needed to better evaluate the marine and continental contributions to the natural changes in atmospheric concentrations of these trace gases under various climatic conditions. Similarly, from new analytical developments in mass spectrometry, we are expecting in the near future to use the isotopic signatures of the $\mathrm{CH}_{4}$ paleo-record to discriminate between different sources such as wetland emissions and clathrate decomposition.

The paleorecord of aerosols and trace gases (in particular $\mathrm{CH}_{4}$ ) should provide information about the evolution of atmospheric chemistry and the oxidizing capacity of the atmosphere in the past. However, we are still far from getting a clear picture of $\mathrm{OH}$ concentration changes under different climatic conditions. The aerosol record documents various processes such as: aerosol transport in the past, changes in sources due to surface environmental changes, possible role of continental dust on marine productivity (see Chapter 4 , Section 4.2.2) and atmospheric chemistry (Dentener et al. 1996), and atmospheric and climatic impact of short term events (volcanic eruptions, meteorites). We can still learn much more from the past and large efforts should be made to evaluate the climatic role of aerosols. Aerosols are a major uncertainty when evaluating the anthropogenic perturbation to the radiative mass balance of the earth (cf. Chapter 5 Houghton et al. 2001).

Finally, ice core results clearly demonstrate the overall correlation between greenhouse trace-gases and climate over glacial-interglacial cycles. This highlights the potential of past records to inform our understanding of climate sensitivity to greenhouse gases under different climatic conditions. The correlation of greenhouse trace gases and climate provides tests for climate models intended to simulate future responses to increasing concentrations of greenhouse gases. 


\section{References}

Abyzov SS, Mitskevitch IN, Zhukova TY, Kuzhinovskii VA, Poglazova MN (1993) Microorganism numbers in the deep layers of the central Antarctic ice-sheet.

Alley RB (2000) The Younger Dryas cold interval as viewed from central Greenland. Quaternary Science Reviews 19:213-226

An Z (2000) The history and variability of the East Asian paleomonsoon climate. Quaternary Science Reviews 19:171187

An Z, Porter SC (1997) Millenial-scale oscillations during the last interglaciation in central China. Geology 25:603-606

Anklin M, Barnola J-M, Schwander J, Stauffer B, Raynaud B (1995) Processes affecting the $\mathrm{CO}_{2}$ concentrations measured in Greenland ice. Tellus 47 B:461-470

Anklin M, Schwander J, Stauffer B, Tschumi J, Fuchs A, Barnola JM, Raynaud D (1997) $\mathrm{CO}_{2}$ record between 40 and $8 \mathrm{kyr}$ B.P. from the Greenland Ice Core Project ice core. Journal of Geophysical Research 102:26 539-26 546

Barnola J-M, Pimienta P, Raynaud D, Korotkevich YS (1991) $\mathrm{CO}_{2}$-climate relationship as deduced from the Vostok ice core: A re-examination based on new measurements and on a re-evaluation of the air dating. Tellus 43:83-90

Barnola JM (1999) Status of the atmospheric $\mathrm{CO}_{2}$ reconstruction from ice cores analyses. Tellus Series B-Chemical and Physical Meteorology 51 (2):151-155

Basile I, Grousset FE, Revel M, Petit J-R, Biscaye BE, Barkov NI (1997) Patagonian origin of glacial dust deposited in East Antarctica (Vostok and Dome C) during glacial stages 2, 4 and 6. Earth and Planetary Science Letters 146:573-579

Battle M, Bender M, Sowers T, Tans PP, Butler JH, Elkins JW, Ellis JT, Conway T, Zhang N, Lang P, Clarke AD (1996) Atmospheric gas concentrations over the past century measured in air from firn at the South Pole. Nature 383:231235

Berger A, Loutre MF, Gallée H (1998) Sensitivity of the LLN climate model to the astronomical and $\mathrm{CO}_{2}$ forcings over the last 200 ky. Climate Dynamics 14:615-629

Bigler M, Wagenbach D, Fischer H, Kipfstuhl J, Miller H, Sommer S, Stauffer B (in press) Sulphate record from a norheast Greenland ice core over the last 1200 years based on continuous flow analysis. Annals of Glaciology 35:

Biscaye PE, Grousset FE, Revel M, VanderGaast S, Zielinski GA, Vaars A, Kukla G (1997) Asian provenance of glacial dust (stage 2) in the Greenland Ice Sheet Project 2 ice core, Summit, Greenland. Journal of Geophysical Research 102:26765-26782

Blake DR, Rowland FS (1987) Continuing worldwide increase in tropospheric methane, 1978 to 1987. Science 239:1129-1131

Blunier T, Brook EJ (2001) Timing of millenial-scale climate change in Antarctica and Greenland during the Last Glacial period. Science 291:109-112

Blunier T, Chappellaz J, Schwander J, Stauffer B, Raynaud D (1995) Variations in atmospheric methane concentration during the Holocene epoch. Nature 374:46-49

Blunier T, J. Chappellaz, J. Schwander, J.-M. Barnola, T. Desperts, B. Stauffer, Raynaud D (1993) Atmospheric methane, record from a Greenland ice core over the last 1000 years. Journal of Geophysical Research 20:2219-2222

Blunier T, Chappellaz J, Schwander J, Dällenbach A, Stauffer B, Stocker TF, Raynaud D, Jouzel J, Clausen HB, Hammer CU, Johnsen SJ (1998) Asynchrony of Antarctic and Greenland climate change during the last glacial period. Nature 394:739-743

Briffa KR, Jones PD, Schweingruber FH, Osborn TJ (1998) Influence of volcanic eruptions on Northern Hemisphere summer temperature over the past 600 years. Nature 393:450-455
Brook EJ, Harder S, Severinghaus J, Steig EJ, Sucher M (2000) On the origin and timing of rapid changes in atmospheric methane during the last glacial period. Global Biogeochemical Cycles 14:559-572

Chappellaz J, Blunier T, Raynaud D, Barnola JM, Schwander J, Stauffer B (1993) Synchronous changes in atmospheric $\mathrm{CH}_{4}$ and Greenland climate between 40 and 8 kyr BP. Nature 366:443-445

Chappellaz J, Blunier T, Kints S, Dällenbach A, Barnola J-M, Schwander J, Raynaud D, Stauffer B (1997) Changes in the atmospheric $\mathrm{CH}_{4}$ gradient between Greenland and Antarctica during the Holocene. Journal of Geophysical Research 102:15987-15999

Charlson RJ, Lovelock JE, Andreae MO, Warren SG (1998) Oceanic phytoplankton, atmospheric sulphur, cloud albedo and climate. Nature 326:655-661

Chen FH, Bloemendale J, Wang JM, Li JJ, Oldfield F (1997) High-resolution multi-proxy climate records from Chinese loess: evidence for rapid climatic changes over the last 75 kyr. Palaeogeography, Palaeoclimatology, Palaeoecology 130:323-335

Christner BC, Mosley-Thompson E, Thompson LG, Zagorodnov V (2000) Recovery and identification of viable bacteria immured in glacial ice. Icarus 144:479-485

Cragin JH, Herron MM, Langway CC, Jr. GK (1977) Interhemispheric comparison of changes in the composition of atmospheric precipitation during the late Cenozic era. In: Dunbar MJ (ed.) Polar Oceans. Arctic Institute of North America, Calgary pp. 617-631

Craig H, Chou CC (1982) Methane: the record in polar ice cores. Geophysical Research Letters 9:1221-1224

Craig H, Horibe Y, Sowers T (1988) Gravitational separation of gases and isotopes in polar ice caps. Science 242:1675-1678

Crutzen PJ, Brühl C (1993) A model study of atmospheric temperatures and the concentrations of ozone, hydroxyl, and some other photochemically active gases during the glacial, the pre-industrial Holocene and the present. Geophysical Research Letters 20:1047-1050,

Dällenbach A, Blunier T, Flückiger J, Stauffer B, Chappellaz J, Raynaud D (2000) Changes in the atmospheric $\mathrm{CH}_{4}$ gradient between Greenland and Antarctica during the Last Glacial and the transition to the Holocene. Geophysical Research Letters

Dansgaard W, Johnsen SJ, Clausen HB, Dahl-Jensen D, Gundestrup NS, Hammer CU, Hvidberg CS, Steffensen JP, Sveinbjornsdottir AE, Jouzel J, Bond G (1993) Evidence for general instability of past climate from a 250 -kyr ice-core record. Nature 364:218-220

De Angelis M, Legrand M (1995) Preliminary investigations of post depositional effects on $\mathrm{HCl}, \mathrm{HNO}_{3}$ and organic acids in polar firn layers. In: Delmas RJ (ed.) Ice CoreStudies of Global Biogeochemical Cycles. Springer Verlag, pp. 369390

De Angelis M, Barkov NI, Petrov VN (1987) Na Aerosol concentrations over the last climatic cycle (160 kyr) from an Antarctic ice coreture. Nature 325:318-321

Delmas RJ (1993) A natural artefact in Greenland ice-core $\mathrm{CO}_{2}$ measurements. Tellus 45B:391-396

Delmonte B, Petit J-R, Maggi V (in press) Glacial to Holocene implications of the new 27,000 year dust record from the EPICA Dome C (East Antarctica) ice core. Climate Dynamics

Delmonte B, Petit J-R, Maggi V (in press) LGM-Holocene changes and Holocene millennial-scale oscillations of dust particles in the EPICA-Dome $\mathrm{C}$ ice core (East Antarctica). Annals of Glaciology

Dentener FJ, Carmichael GR, Zhang Y, Lelieveld J, Crutzen PJ 
(1996) Role of mineral aerosol as a reactive surface in the global troposphere. Journal of Geophysical Research 101:22869-22889

Dibb JE, Rasmussen RA, Mayewski PA, Northern HG (1993) Northern Hemisphere concentrations of methane and nitrous oxide since 1800: results from the Mt Logan and 20D ice cores. Chemosphere 27:2413-2423

Ding ZL, Rutter N, Yu ZW, Guo ZT, Zhu RX (1995) Ice-volume forcing of East Asian winter monsoon variations in the past 800,000 years. Quaternary Research 44:149-159

Etheridge DM, Pearman GI (1988) Atmospheric trace-gas variations as revealed by air trapped in an ice-core from Law Dome, Antarctica. Annals of Glaciology 10: 28-33

Etheridge DM, G.I. Pearman, Fraser PJ (1992) Changes in tropospheric methane between 1841 and 1978 from a high accumulation-rate Antarctic ice core. Tellus 44 B:282-294

Etheridge DM, Steele LP, Langenfields RL, Francey RJ, Barnola J-M, Morgan VI (1996) Natural and anthropogenic changes in atmospheric $\mathrm{CO}_{2}$ over the last 1000 years from air in Antarctic ice and firn. Journal of Geophysical Research 101:4115-4128

Etheridge DM, Steele LP, Francey RJ, Langenfields RL (1998) Atmospheric methane between 1000 A.D. and present: Evidence of anthropogenic emissions and climatic variability. Journal of Geophysical Research 103:1597915993

Fang X (1995) The origin and provenance of Malan loess along the eastern margin of Qinghai-Xizang (Tibetan) Plateau and its adjacent area. Science in China (Series B) 38:876-887

Fang XM, Ono Y, Fukusawa H, Pan BT, Li J, Guan DH, Oi K, Tsukamoto S, Torii M, Mishima T (1999) Asian summer monsoon instability during the past 60,000 years: magnetic susceptibility and pedogenic evidence from the western Chinese Loess Plateau. Earth and Planetary Science Letters 168: 219-232

Flückiger J, Dällenbach A, Blunier T, Stauffer B, Stocker TF, Raynaud D, Barnola JM (1999) Variations in atmospheric $\mathrm{N}_{2} \mathrm{O}$ concentration during abrupt climatic changes. Science 285:227-230

Flückiger J, Monnin E, Stauffer B, Schwander J, Stocker TF, Chappellaz J, Raynaud D, Barnola JM (2001) High resolution Holocene $\mathrm{N}_{2} \mathrm{O}$ ice core record and its relationship with $\mathrm{CH}_{4}$ and $\mathrm{CO}_{2}$. Global Biogeochemical Cycles

Fuhrer K, Neftel A, Anklin M, Maggi V (1993) Continuous measurements of hydrogen peroxide, formaldehyde, calcium and ammonium concentrations along the new GRIP ice core from Summit, Central Greenland. Atmospheric Environment 27A: $1873-1880$

Fung I, John J, Lerner J, Matthews E, Prather M, Steele LP, Fraser PJ (1991) Three-dimensional model synthesis of the global methane cycle. Journal of Geophysical Research 96:13033-13065

Gasse F (2000) Hydrological changes in the African tropics since the Last Glacial Maximum. Quaternary Science Reviews 19:189-211

Gorham E (1991) Northern peatlands; role in carbon cycle and probable responses to climate change. Ecological Applications 1:182-195

Guo ZT, Liu TS, Guiot J, Wu N, Lu H, Han J, Liu J, Gu Z (1996) High frequency pulses of East Asian monsoon climate in the two glacaitions: link with the North Atlantic. Climate Dynamics 12:701-709

Guo ZT, Liu TS, Fedroff N, Wei LY, Ding ZL, Wu NQ, Lu HY, Jiang WY, An ZS (1998) Climate extremes in loess of China coupled with the strength of deep -water formation in the North Atlantic. Global and Planetary Change 18:113-128

Haan D, Raynaud D (1998) Ice core record of CO variations during the last two millennia: atmospheric implications and chemical interactions within the Greenland ice. Tellus Series B-Chemical and Physical Meteorology 50:253-262

Houghton JT, Filho LGM, Callander BA, Harris N, A.
Kattenberg (1995) Climate Change 1995: The Science of Climate Change Cambridge University Press, Cambridge, U.K

Houghton JT, Ding Y, Griggs DG, Noguer M, Linden PJvd, Dai X, Maskell K, Johnson CA (2001) Climate Change 2001: The Scientific Basis. Contribution of Working Group I to the Third Assessment Report of the IPCC, 2001. Cambridge University Press

Houghton RW, Tourre YM (1992) Characteristics of lowfrequency sea surface temperature fluctuations in the tropical Atlantic. Journal of Climate 5:756-771

Indermühle A, Stocker TF, Fischer H, Smith HJ, Joos F, Wahlen M, Deck B, Mastroianni D, Tschumi J, Blunier T, Meyer R, Stauffer B (1999) High-resolution Holocene $\mathrm{CO}_{2}$-record from the Taylor Dome ice core (Antarctica). Nature 398:121-126

Indermühle A, Stocker TF, Joos F, Fischer H, Smith HJ, Wahlen M, Deck B, Mastroianni D, Tschumi J, Blunier T, Meyer R, Stauffer B (1999) Holocene carbon-cycle dynamics based on $\mathrm{CO}_{2}$ trapped in ice at Taylor Dome, Antarctica. Nature 398:121-126

Johnsen SJ, Dansgaard W, Clausen HB, C.C. Langway J (1972) Oxygen isotope profiles through the Antarctic and Greenland ice sheets. Nature 235:429-434

Joos F, Bruno M, Fink R, Siegenthaler U, Stocker TF, LeQuéré C, Sarmiento JL (1996) An efficient and accurate representation of complex oceanic and biospheric models of anthropogenic carbon uptake. Tellus 48B:397-417

Kammen DM, Marino BD (1993) On the origin and magnitude of pre-industrial anthropogenic $\mathrm{CO}_{2}$ and $\mathrm{CH}_{4}$ emissions. Chemosphere 26:69-86

Kaplan JO (in press) Wetlands at the Last Glacial Maximum: Distribution and methane emissions. Geophysical Research Letters 29:1-4

Keeling CD, Whorf TP (2000) Atmospheric $\mathrm{CO}_{2}$ records from sites in the SIO air sampling network. In: Trends: $A$ Compendium of Data on Global Change. Carbon Dioxide Information Analysis Center, Oak Ridge National Laboratory, U.S. Department of Energy, Oak Ridge, Tennessee

Keeling CD, Bacastow RB, Carter AF, Piper SC, Whorf TP, Heimann M, Roeloffzen H (1989) A three dimensional model of atmospheric $\mathrm{CO}_{2}$ transport based on observed winds: 1. Analysis of observational data. In: Peterson DH (ed.) Aspects of climate variability in the Pacific and Western Americas. AGU, Washington pp. 165-236

Kennett JP, Cannariato KG, Hendy IL, Behl RJ (2000) Carbon isotopic evidence for methane hydrate instability during Quaternary interstadials. Science 288:128-133

Khalil MAK, Rasmussen RA (1982) Secular trends of atmospheric methane $\left(\mathrm{CH}_{4}\right)$. Chemosphere 11:877-883

Kohfeld KE, Harrison SP (2000) How well can we simulate past climates? Evaluating the models using global palaeoenvironmental datasets. Quaternary Science Reviews 19:321-346

Kroeze C, Mosier A, Bowman L (1999) Closing the global $\mathrm{N}_{2} \mathrm{O}$ budget: A retrospective analysis 1500-1994. Global Biogeochemical Cycles 13:1-8

Kukla G, Heller F, Liu XM, Xu TC, Liu TS, An ZS (1988) Pleistocene climates in China dated by magnetic susceptibility. Geology 16:811-814

Lang C, Leuenberger M, Schwander J, Johnsen S (1999) $16^{\circ} \mathrm{C}$ rapid temperature variation in central Greenland 70,000 years ago. Science 286:934-937

Legrand M, Feniet-Saigne C (1991) Strong El Niño revealed by methanesulphonic acid in South Polar snow layers? Geophysical Research Letters 18:187-190

Legrand M, Lorius C, Barkov NI, Petrov VN (1988) Atmospheric chemistry changes over the last climatic cycle $(160,000 \mathrm{yr})$ from Antarctic ice. Atmospheric Environment 22:317-331 
Legrand M, Feniet-Saigne C, Saltzman ES, Germain C (1992) Spatial and temporal variations of methanesulfonic acid and non sea salt sulfate in Antarctic ice. Journal of Atmospheric Chemistry 14:245-260

Legrand M, Feniet-Saigne C, Saltzman ES, Germain C, Barkov NI, Petrov VN (1991) Ice-core record of oceanic emissions of dimethylsulphide during the last climatic cycle. Nature 350:144-146

Leuenberger M, Lang C, Schwander J (1999) $\delta 15 \mathrm{~N}$ measurements as a calibration tool for the paleothermometer and gas-ice age differences. A case study for the $8200 \mathrm{~B}$. P. event on GRIP ice. Journal of Geophysical Research 104:22163-22169

Leuschner DC, Sirocko F (2000) The low-latitude monsoon climate during Dansgaard-Oeschger cycles and Heinrich Events. Quaternary Science Reviews 19:243-254

Li J-J, Fang M-X, Wang J, Zhong W, Cao J, Pan B, Ma H, Zhu J, Zhou S, Chen F, Wang J, Ma Y (1995) Uplift of the Qinghai-Xizang (Tibet) plateau and global change Lanzhou University Press, 207 pp

Liss PS, Hatton AD, Malin G, Nightingale PD, Turner SM (1997) Marine sulphur emissions. Philosohpical Transactions of the Royal Society, London 352:159-168

Lu H, VanHuissteden K, An Z, Nugteren G, Vandenberghe J (1999) East Asia winter monsoon variations on a millennial time-scale before the last glacial-interglacial cycle. Jounal of Ouaternary Science 14:101-110

Machida T, Nakazawa T, Fujii Y, Aoki S, Watanabe O (1995) Increase in the atmospheric nitrous oxide concentration during the last 250 years. Geophysical Research Letters 22:2921-2924

Marchal O, Stocker TF, Joos F, Indermühle A, Blunier T, Tschumi J (1999) Modelling the concentration of atmospheric $\mathrm{CO}_{2}$ during the Younger Dryas climate event. Climate Dynamics 15:341-354

Martinerie P, Brasseur GP, Granier C (1995) The chemical composition of ancient atmospheres: A model study constrained by ice core data. Journal of Geophysical Research 100:14291-14304

Mayewski PA, Meeker LD, Twickler MS, Whitlow S, Yang Q, Lyons WB, Prentice M (1997) Major features and forcing of high-latitude northern hemisphere atmospheric circulation using a 110,000-year-long glaciochemical series. Journal of Geophysical Research 102:26345-26366

Mayewski PA, Meeker LD, Whitlow S, Twickler MS, Morrison MC, Bloomfield P, Bond GC, Alley RB, Gow AJ, Grootes PM, Meese DA, Ram M, Taylor KC, Wumkes W (1994) Changes in atmospheric circulation and ocean ice cover over the North Atlantic during the last 41,000 years. Science 263:1747-1751

McEvedy C, Jones R (1979) Atlas of world population history New York, 166-167

Miller SL (1969) Clathrate hydrates of air in Antarctic ice. Science 165:489-490

Monnin E, Indermühle A, Dällenbach A, Flückiger J, Stauffer B, Stocker TF, Raynaud D, Barnola J-M (2001) Atmospheric $\mathrm{CO}_{2}$ concentrations over the Last Glacial Termination. Science 291:112-114

Mosley-Thompson E (1992) Paleoenvironmental conditions in Antarctica since A.D. 1500: ice core evidence. In: Bradley RS and Jones PD (eds.) Climate Since A.D. 1500. Routledge, London pp. 572-591

Mulvaney R, Pasteur E, Peel DA, Saltzman ES, Whung PY (1992) The ratio of MSA to non-sea-salt sulphate in Antarctic Peninsula ice cores. Tellus 44B:295-303

Nakazawa T, Machida T, Tanaka M, Fujii Y, Aoki S, Watanabe O (1993) Differences of the atmospheric $\mathrm{CH}_{4}$ concentration between the arctic and antarctic regions in pre-industrial/preagricultural era. Geophysical Research Letters 20:943-946

Naqvi SWA, Jayakumar DA (2000) Ocean biogeochemistry and atmospheric composition: Significance of the Arabian Sea.
Current Science 78:289-299

Neftel A, Oeschger H, Staffelbach T, Stauffer B (1988) CO record in the Byrd ice core 50000-5000 years BP. Nature 331:609-611

Nisbet EG (1990) The end of the ice age. Canadian Journal of Earth Sciences 27:148-157

Oba T, Pederson T (1999) Paleoclimate significance of eolian carbonates supplied to the Japan Sea during the last glacial maximum. Paleoceanography 14:34-41

Oeschger H, Neftel A,Staffelbach T, Stauffer B (1989) The dilemma of the rapid variations in $\mathrm{CO} 2$ in Greenland ice cores. Annals of Glaciology 10: 215-216.

Ono Y, Naruse T (1997) Snowline elevation and eolian dust flux in the Japanese islands during isotope stages 2 and 4 . Quaternary International 37:45-54

Ono Y, D. Liu, Zhou YM (1997) Paleoenvironments of the Tibetan Plateau viewed from glacial fluctuations at the northern foot of the West Kunlun Mountains. Journal of Tokyo Geographical Society 106:184-198

Pearman GI, Etheridge D, Silva FD, Fraser PJ (1986) Evidence of changing concentrations of atmospheric $\mathrm{CO}_{2}, \mathrm{~N}_{2} \mathrm{O}$ and $\mathrm{CH}_{4}$ from air bubbles in Antarctic ice. Nature 320:248-250

Pedersen TF, Bertrand P (2000) Influences of oceanic rheostats and amplifiers on atmospheric $\mathrm{CO}_{2}$ content during the Late Quaternary. Quaternary Science Reviews 19:273-283

Pépin L, Raynaud D, Barnola J-M, Loutre MF (in press) Hemispheric roles of climate forcings during glacialinterglacial transitions as deduced from the Vostok record and LLN-2D model experiments. Journal of Geophysical Research 106:31885-31892

Petit JR, L. Mounier, J. Jouzel, Y.S. Korotkevich, V.I. Kotlyakov, Lorius C (1990) Palaeoclimatological and chronological implications of the Vostok core dust record. Nature 343:56-58

Petit JR, Jouzel J, Raynaud D, Barkov NI, Barnola JM, Basile I, Bender M, Chappellaz J, Davis M, Delaygue G, Delmotte M, Kotlyakov VM, Legrand M, Lipenkov VY, Lorius C, Pepin L, Ritz C, Saltzman E, Stievenard M (1999) Climate and atmospheric history of the past 420,000 years from the Vostok ice core, Antarctica. Nature 399:429-436

Petit-Maire N, Fontugne M, Rouland C (1991) Atmospheric methane ratio and environmental changes in the Sahara and Sahel during the last 130 kyrs. Palaeogeography, Palaeoclimatology, Palaeoecology 86:197-204

Porter SC, An ZS (1995) Correlation between climate events in the North Atlantic and China during the last glaciation. Nature 375:305-308

Prinn R, D. Cunnold, R. Rasmussen, P. Simmonds, F. Alyea, A. Crawford, P. Fraser, Rosen R (1990) Atmospheric emissions and trends of nitrous-oxide deduced from 10 years of AleGauge data. Journal of Geophysical Research-Atmospheres 95:18369-18385

Rasmussen RA, Khalil MAK (1984) Atmospheric methane in the recent and ancient atmospheres: concentrations, trends, and interhemispheric gradient. Journal of Geophysical Research 89:11599-11605

Raynaud D, Jouzel J, Barnola JM, Chappellaz J, Delmas RJ, Lorius C (1993) The ice record of greenhouse gases. Science 259:926-933

Rommelaere V, Arnaud L, Barnola J-M (1997) Reconstructing recent atmopheric trace gas concentrations from polar firn and bubbly ice data by inverse methods. Journal of Geophysical Research 102:30069-30083

Saigne C, Legrand M (1987) Measurements of methanesulphonic acid in Antarctic ice. Nature 330:240-242

Sato M, Hansen JE, McCormick MP, Pollack JB (1993) Stratospheric aerosol optical depths, 1850-1990. Jounal of Geophysic Research- Atmosphere 98:22987-22994

Schulz H, vonRad S, Erlenkeuser H (1998) Correlation between Arabian Sea and Greenland climate oscillations of the past 110,000 years. Nature 393:54-57 
Schwander J (1996) Gas diffusion in firn. In: Wolff EW and Bales RC (eds.) Chemical Exchange Between the Atmosphere and Polar Snow. pp. 527-540

Schwander J, Stauffer B (1984) Age difference between polar ice and the air trapped in its bubbles. Nature 311:45-47

Schwander J, Stauffer B (1989) The transformation of snow to ice and the occlusion of gases. In: Oeschger $\mathrm{H}$ and Langway CC (eds.) The Environmental Record in Glaciers and Ice Sheets. John Wiley, New York pp. 53-67

Schwander J, Barnola J-M, Andrié C, Leuenberger M, Ludin A, Raynaud D, Stauffer B (1993) The age of the air in the firn and the ice at Summit, Greenland. Journal of Geophysical Research 98:2831-2838

Severinghaus JP, Brook EJ (1999) Abrupt climate change at the end of the Last Glacial period inferred from trapped air in polar ice. Science 286:930-934

Severinghaus JP, Sowers T, Brook EJ, Alley RB, Bender ML (1998) Timing of abrupt climate change at the end of the Younger Dryas interval from thermally fractionated gases in polar ice. Nature 391:141-146

Shackleton NJ (2000) The 100,000-year ice-age cycle identified and found to lag temperature, carbon dioxide, and orbital eccentricity. Science 289:1897-1902

Shoji H, Miyamoto A, Kipfstuhl J, Langway CC (2000) Microscopic observations of air hydrate inclusions in deep ice core samples. In: Hondoh T (ed.) Physics of ice core records. Hokkaido University Press, Sapporo

Sowers T (2001) The N2O record spanning the penultimate deglaciation from the Vostok ice core. Journal of Geophysical Research-Atmospheres

Stauffer B, Fischer G, Neftel A, Oeschger H (1985) Increase of atmospheric methane recorded in Antarctic ice core. Science 229:1386-1388

Stauffer B, Hofer H, Oeschger H, Schwander J, Siegenthaler U (1984) Atmospheric $\mathrm{CO}_{2}$ concentration during the last glaciation. Annals of Glaciology 5:160-164

Stauffer B, Blunier T, Dällenbach A, Indermühle A, Schwander J, Stocker TF, Tschumi J, Chappellaz J, Raynaud D, Hammer CU, Clausen HB (1998) Atmospheric CO2 concentration and millennial-scale climate change during the last glacial period. Nature 392:59-62

Street-Perrott FA (1992) Tropical wetland sources. Nature 355:23-24

Subak S (1994) Methane from the house of Tudor and the Ming dynasty: Anthropogenic emissions in the sixteenth century. Chemosphere 29:843-854

Tada R, Irino T, Koizumi I (1999) Land-ocean linkage over orbital and millenial timescales recorded in the late Quaternary sediments of the Japan Sea. Paleoceanography $14: 236-247$

Thompson AM (1992) The oxidizing capacity of the Earth's atmosphere: probable past and future changes. Science 256:1157-1168

Thompson AM, Chappellaz JA, Fung IY, Kucsera TL (1993) Atmospheric methane increase since the Last Glacial Maximum. 2. Interactions with oxidants. Tellus 45B:242257

Thompson LG (1995) Late Glacial Stage and Holocene tropical ice core records from Huascaran, Peru. Science 269:46-50

Thompson LG (2000) Ice core evidence for climate change in the Tropics: implications for our future. Quaternary Science Reviews 19:19-35

Thompson LG, Mosley-Thompson E (1981) Microparticle concentration variations linked with climatic change: Evidence from polar ice cores. Science 212:812-815

Thompson LG, Davis ME, Mosley-Thompson E, Liu K-B (1988) Pre-Incan agricultural activity recorded in dust layers in two tropical ice cores. Nature 336:763-765

Thompson LG, Mosley-Thompson E, Davis ME, Lin N, Yao T, Dyurgerov M, Dai J (1993) "Recent warming": ice core evidence from tropical ice cores, with emphasis on central
Asia. Global and Planetary Change 7:145-156

Thompson LG, Mosley-Thompson E, Davis ME, Lin PN, Dai J, Bolzan JF, Yao T (1995) A 1000 year climate ice-core record from the Guliya ice cap, China: its relationship to global climate variability. Annals of Glaciology 21:175-181

Tschumi J, Stauffer B (2000) Reconstructing past atmospheric $\mathrm{CO}_{2}$ concentration based on ice- core analyses: open questions due to in situ production of $\mathrm{CO}_{2}$ in the ice. Journal of Glaciology 46:45-53

Vardy SR, Warner BG, Turunen J, Aravena R (2000) Carbon accumulation in permafrost peatlands in the Northwest Territories and Nunavut, Canada. Holocene 10:273-280

Wagnon P, Delmas RJ, Legrand M (1999) Loss of volatile acid species from upper firn layers at Vostok, Antarctica. Journal of Geophysical Research 104:3423-3431

Wang L, Oba T (1998) Tele-connections between east Asian monsoon and the high-latitude climate: A comparison between the GISP2 ice core record and the high resolution marine records from the Japan and South China Seas. The Quaternary Research (Daiyonki-Kenkyu) 37:211-219

Wang YJ, Cheng H, Edwards RL, An Z, Wu J, Shen C-C, Dorale JA (2001) A high-resolution absolute-dated late Pleistocene monsoon record from Hulu Cave, China. Science 294:23452348

Watson AJ, Liss PS (1998) Marine biological controls on climate via the carbon and sulphur geochemical cycles. Philosohpical Transactions of the Royal Society, London 353:41-51

Weaver AJ, Eby M, Fanning AF, Wiebe EC (1998) Simulated influence of carbon dioxide, orbital forcing and ice sheets on the climate of the Last Glacial Maximum. Nature 394:847853

Wolff EW (1996) Location, movement and reactions of impurities in polar ice. In: Wolff EW and Bales RC (eds.) Chemical Exchange between the Atmosphere and Polar Snow. Springer, Berlin pp. 541-560

Xiao JL, Porter SC, An ZS, Kumai H, Yoshikawa S (1995) Grain size of quartz as an indicator of winter monsoon strength on the Loess Plateau of central China during the last 130,000 years. Quaternary Research 43:22-29

Xiao JL, An ZS, Liu TS, Inouchi Y, Kumai H, Yoshikawa S, Kondo Y (1999) East Asian monsoon variation during the last 130,000 years: evidence from the Loess Plateau of central China and Lake Biwa of Japan. Quaternary Science Reviews 18:147-157

Zhang DE (1984) Synoptic climatic studies of dust fall in China since the historic time. Quaternary Science Reviews Ser.B27:825-836 